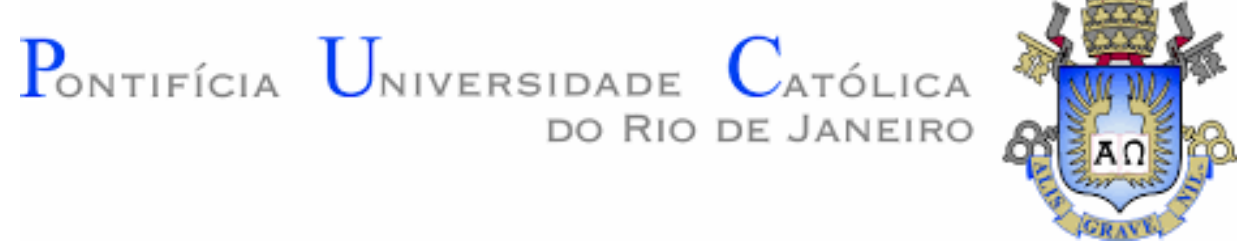

Mariana Adão da Silva

Nó Líquido: da subversão do sujeito à subversão da política

Dissertação de mestrado

Dissertação apresentada como requisito parcial para obtenção do grau de Mestre pelo Programa de Pós-Graduação em Psicologia (Psicologia Clínica), junto ao Departamento de Psicologia do Centro de Teologia e Ciências Humanas da PUC-Rio.

Orientador: Prof. Marcus André Vieira

Rio de Janeiro, Março de 2019. 


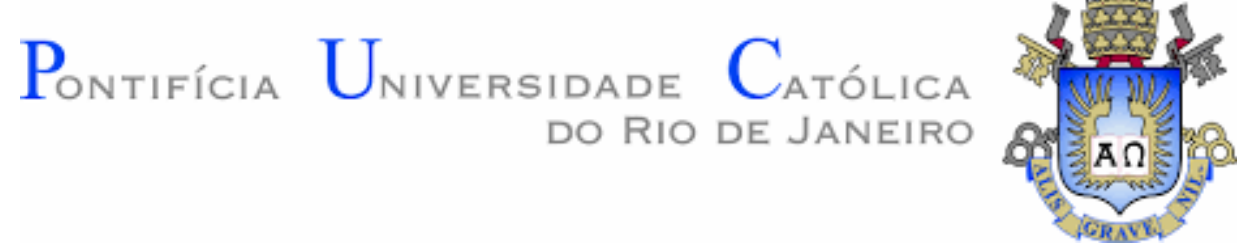

Mariana Adão da Silva

\section{Nó Líquido: \\ da subversão do sujeito à subversão da política}

Dissertação apresentada como requisito parcial para obtenção do grau de Mestre pelo Programa de Pós-Graduação em Psicologia (Psicologia Clínica), junto ao Departamento de Psicologia do Centro de Teologia e Ciências Humanas da PUC-Rio.

Prof. Marcus André Vieira

Orientador

Departamento de Psicologia - PUC-Rio

Prof. Maria Helena Costa Zamora

Departamento de Psicologia - PUC-Rio

Prof. Fernando Cardoso Lima Neto Departamento de Ciências Sociais - PUC-Rio

Rio de Janeiro, 13 de março de 2019. 
Todos os direitos reservados. É proibida a reprodução total ou parcial do trabalho sem autorização da universidade, da autora e do orientador.

\section{Mariana Adão da Silva}

Graduou-se em Psicologia pela Pontifícia Universidade Católica de São Paulo em 2006. Especialista em Saúde Mental Pela Universidade Federal do Rio de Janeiro (2011). É psicóloga, psicanalista e pesquisadora.

Ficha Catalográfica

Silva, Mariana Adão da

Nó líquido : da subversão do sujeito à subversão da política / Mariana Adão da Silva ; orientador: Marcus André Vieira. - 2019.

87 f. ; $30 \mathrm{~cm}$

Dissertação (mestrado)-Pontifícia Universidade Católica do Rio de Janeiro, Departamento de Psicologia, 2019.

Inclui bibliografia

1. Psicologia - Teses. 2. Zygmunt Bauman. 3. Sigmund Freud. 4. Jorge Alemán. 5. Ernesto Laclau. 6. Jacques Lacan. I. Vieira, Marcus André. II. Pontifícia Universidade Católica do Rio de Janeiro. Departamento de Psicologia. III. Título. 


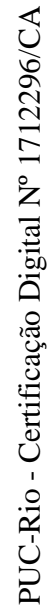


Para todos, sem exceção, que me compõem a vida. Meus fios de trança. 


\section{Agradecimentos}

Ao Marcus André Vieira, pela persistência, paciência e carinho.

À PUC-SP, pela formação com seus professores generosos.

À PUC, pelo espaço e pela bolsa que nos permite viver isso de forma mais qualificada e sustentável.

O presente trabalho foi realizado com apoio da Coordenação de Aperfeiçoamento de Pessoal de Nível Superior - Brasil (CAPES) - Código de Financiamento 001.

À prof. Maria Helena Zamora, que admiro à distância e que me deu, agora, o prazer de sua presença.

Ao prof. Fernando Cardoso Neto, que teve a generosidade de se debruçar sobre um tema que, a princípio, poderia lhe parecer tão distinto.

À Monica Visco, minha analista desde sempre, que me ensinou que só o desejo produz em nós e a partir de nós o que (nos) vale.

À Thereza Adão e Antônio Alves, pais amados, que me ensinaram que "o inconsciente é a política”. Por seus desejos por mim. Por seus desejos pelo "sócio"...

À Clarice Arantes, Luísa Moraes, Alejandra Vargas, Gabriel Tupinambá e Rafa Fisher que, em vários momentos, quer saibam ou não, foram meus verdadeiros companheiros de jornada.

À Thereza De Felice, pela revisão carinhosa.

Á Marinela Porto, pelas "lembranças" frente às burocracias e angústias do processo.

À Julia, Nino e Priscila, amigas “das tortas”, porque nunca seria sem elas...

À Sila Costa, Cristina Vandenboch, Gabriela Terra e Fernanda Forato, amigas paulistas que sempre me agregam com esta estranha noção de pertencimento.

Ao Rodrigo, companheiro de uma vida inteira, mesmo antes de conhecê-lo. 


\section{Resumo}

da Silva, Mariana Adão; Vieira, Marcus André. Nó Líquido: da subversão do sujeito à subversão da política. Rio de Janeiro, 2019. 87p. Dissertação de Mestrado - Departamento de Psicologia, Pontifícia Universidade Católica do Rio de Janeiro.

Esta dissertação propõe uma leitura da especificidade do laço social na atualidade, assim como propõe uma maneira como, a partir deste laço, poderia ser decantada uma política contemporânea. Para esta costura, uma leitura do sociólogo Zygmunt Bauman fornece balizas para delimitarmos o estado atual do laço social. Em seguida, algumas das perspectivas de Sigmund Freud, com relação ao social e aos modos de organização grupal, especialmente quanto ao lugar que estes dão ao líder, são contrapostas à descrição de Bauman. Jorge Alemán e Ernesto Laclau trazem, então, elementos para a aplicação de conceitos desenvolvidos por Jacques Lacan, a partir de Freud, ao momento político atual, especialmente no que concerne às concepções de solidão comum, significante vazio e ato instituinte. Por fim, os conceitos lacanianos de nó borromeano e sinthome são examinados para localizar em que se apoiam os conceitos de Alemán e Laclau, com referência ao ensino de Lacan. Amarra-se, assim, nossa dissertação, propondo alguma orientação dentro do campo demarcado.

\section{Palavras-chave}

Zygmunt Bauman; Sigmund Freud; Jorge Alemán; Ernesto Laclau; Jacques Lacan; solidão comum; significante vazio; ato instituinte; nó borromeano; sinthome. 


\section{Abstract}

da Silva, Mariana Adão; Vieira, Marcus André (Advisor). Liquid node: from the subversion of the subject to the subversion of the politics. Rio de Janeiro, 2019. 87p. Dissertação de Mestrado - Departamento de Psicologia, Pontifícia Universidade Católica do Rio de Janeiro.

This dissertation proposes a reading of the specificity of the social tie in the present time, as well as proposes a way where, from this tie, a contemporary politics could be decanted. For this seam, a reading by sociologist Zygmunt Bauman provides reading beacons for delimiting the current state of the social tie. Next, some of Freud's perspectives on the social and modes of group organization, especially as to the place they give to the leader, are opposed to Bauman's description. Jorge Alemán and Ernesto Laclau bring elements for the application of concepts developed by Jacques Lacan from Freud's work to the present political moment, especially in what concerns his conceptions of common solitude, empty signifier and institute act. Finally, the Lacanian concepts of the Borromean node and sinthome are examined with the objective of locating in which the concepts of Alemán and Laclau are supported in the teaching of Lacan. Thus, our dissertation is tied, proposing some orientation within the demarcated field.

\section{Keywords}

Zygmunt Bauman; Sigmund Freud; Jorge Alemán; Ernesto Laclau; Jacques Lacan; common solitude; empty signifier; institute act; borromean node; sinthome. 
Sumário

Introdução

1. Zygmunt Bauman: do moderno à sua pós

1.1 Essa tal modernidade: há pessoas fora do quadro

1.2 Pós-modernidade: um rei caolho ou os insones

- um quinhão de segurança por um quinhão de liberdade

1.3 Uma necessária ordem para borrar o caos

2. Enlaçando: Freud e o laço social

2.1 Totem e tabu: a matriz do laço social

2.2 Psicologia das massas e análise do eu:

o outro social e o lugar do líder

2.3 0 mal-estar na civilização:

a dimensão complexa dos conflitos entre intenções

particulares e construções coletivas

3. Novo piso: Alemán e Laclau

3.1 Dos fins dos sentidos, dos grandes relatos, dos Estados Nacionais:

a crise da unidade

3.2 Atualidade: o pessoal é político

3.3 Solidão comum, significante vazio e ato instituinte:

de que forma e onde se produzem os novos atos?

3.4 A chegada de uma era totalmente política, auto referida: a não necessidade de entidades prévias como constituição de solo comum e um comum que se dá em ato 
4.1 Cada vez mais contrato, cada vez menos instituição

- "o impossível e seus poderes de subversão": nó borromeano

4.2 "Um Pai como um sinthoma como os outros" ou, na ordem dos "des" - sublimados, idealizados: sinthoma

4.3 "Quanto ao uso besta dos nós", quanto ao uso besta de nós:

marcas e invenções

5. Conclusão

6. Referências bibliográficas 
A língua é minha pátria.

Caetano Veloso,

Lingua.

(...) a civilização regula o gozo, donde a civilização remete o fazer civil, a transformar em cidadão, fazer sociável, dito em outros termos, a fazer entrar o gozo no laço social sintomatizado conforme os modelos aceitáveis. (...) a civilização tem a ver com o discurso. Para Lacan, o discurso excede à palavra, vai mais além dos enunciados que realmente se pronunciam. O discurso subsiste sem palavras porque se trata de relações fundamentais que se sustentam da linguagem. O discurso sustenta a realidade, a modela sem supor o consentimento por parte do sujeito. Como o laço social é afetado por esta atualidade? Os laços são pontuais, as coisas não se programam em longo prazo. O modelo é de conexão e desconexão, quase como se vivessem na Internet os sujeitos fazem redes, links (...).

Hebe Tízio, Novas modalidades do laço social. 


\title{
Introdução
}

Política e psicanálise - Vele, revele: de sutis incômodos a imperfeitas produções.

\author{
Pare, repare \\ Cite, recite \\ Salve, ressalve \\ Volte, revolte \\ Trate, retrate \\ Vele, revele \\ Toque, retoque \\ Prove, reprove \\ Clame, reclame \\ Negue, renegue \\ Salte, ressalte, \\ Bata, rebata \\ Fira, refira \\ Quebre, requebre \\ Mexa, remexa \\ Bole, rebole \\ Volta, revolta \\ Corra, recorra \\ Mate, remate \\ Morra, renasça \\ Caetano Veloso e Pedro Novis, \\ Relance
}

O cenário atual é efervescente de mudanças, subversões e conflitos. Transborda desmontes, desconstrói a reconstrução - constrói algo novo -, desloca desejos, desmonta remontes. Reclama, renega, ressalta, para, no passo seguinte, clamar, negar, saltar. Nele, o fluxo contínuo de laços, ocupações, pontuações, reflexões, persistências, insistências e disrupções constituem corpos. E, nestes, ao nosso ver, um elemento se destaca: a perspectiva do furo.

É incômodo que, mais ou menos silencioso, o furo compareça, de forma sublime e trágica, estruturando os trajetos dos sujeitos e de suas civilizações. Sublime e trágica, aliás, até para que, em um segundo momento, tanto para nosso percurso de pesquisa, quanto para as possíveis localizações do sujeito, possam deslizar e fazer parte de um outro lugar - o de amarração - das estruturas e narrativas. É neste lugar que este vazio, inabalavelmente, ex-siste ${ }^{1}$, 
encarnando uma estrutura que, por ela mesma, veicula e possibilita a existência.

É a partir de tal compreensão que buscamos nossa posição e aproximação, ficando com a questão: mas, então, onde se insere tal furo, este que supomos fundamental para estruturar o sujeito hoje? Do que se trata? Como se mostra? Se produz, o que produz?

Como, enfim, lidamos com o furo? Onde se encaixa (se é que se encaixa), no mundo de fronteira e de mudanças da pós-modernidade? Sutis incômodos que apresentam nossas imperfeições, nossos fracassos, nossos equívocos, nossas falhas, nossos hiatos... Aqueles "nossos" que não queremos tão nossos assim.

Nossa aposta é de que, mais do que nunca, é esse furo o principal responsável, na atualidade, por nossos enlaces. Um furo que quebra a única via da identificação para a constituição de nossos vínculos e que aposta, como nunca, na perspectiva da alteridade e no campo das diferenças para a constituição de tal elo. Para não nos liquefazermos no caos, mas também não traçarmos, como única opção, a rigidez dos sólidos bauminiamos: um caminho alternativo. Talvez seja este um bom percurso para nos debruçarmos sobre o que, hoje, enlaça o homem; o que faz liga entre nós. Pensaremos no que tal percurso, já defendido por autores como Jorge Alemán e Ernesto Laclau, e mesmo por Jacques Lacan, poderá produzir.

O que chamamos, a partir da psicanálise, de laço social, trata-se da relação entre os seres. Aquele - e aquela - que se sustenta do discurso e, por meio dele, assume as modalidades da época e marcas de seu tempo.

Nossa pesquisa se inclina sobre este ponto: interrogar o que produz vínculos, hoje, o que enlaça o homem pós-moderno, o que o seduz como (novo) marcador de localização e identidade (ainda poderemos chamá-la assim?) e, a partir disso, produz ato, produz política, produz pólis; produz.

Todas essas questões nos cercam, incessantemente, no mundo atual. Nos mais variados debates e/ou em formato de enigma, a indagação que,

\footnotetext{
${ }^{1} \mathrm{~A}$ ex-sistência se define por relação a certa consistência. A ex-sistência não é, no final das contas, senão esse fora que não é um não-dentro; é, de certa maneira, esse em volta do que se evapora uma substância (LACAN, 2007, p. 19), mas que, em uma espécie de forma subliminar, lhe dá estrutura e oferta consistência.
} 
imediatamente, se coloca, é, então: quem é o homem pós-moderno? Como - e de que forma - se relaciona? Como se expressa? A partir de quais marcas (se) cria e se estabelece? Passando por quais estruturas? Alavancando quais produtos? Quais respostas?

Inicialmente, nos primeiros momentos desta pesquisa, as informações que se apresentavam como possíveis diálogos entre a psicanálise e a política se manifestavam de forma bastante escassa. Com o tempo, no entanto, estas foram se adensando. E, tanto externamente, quanto internamente, em nosso desenvolvimento, pudemos ir estabelecendo um corpo teórico diante do qual alguns caminhos foram se tornando possíveis. As descobertas que, a partir de então, se deram foram produzindo alguns nomes, na direção de um possível texto, daquilo que se procurava. Estes nomes puderam produzir as hipóteses, concepções, reflexões e inflexões aqui apresentadas quanto ao tema abordado.

Em nosso percurso, não sabíamos até que ponto um diálogo entre a psicanálise e a política, de fato, poderia se dar.

No entanto, a própria experiência empírica atual, fez com que este diálogo, mais do que nunca, passasse a se expressar de forma bastante significativa, ratificando sua pertinência. A política era, então, de fato, um objeto a ser estudado, inclusive, pela psicanálise. Mais do que nunca, aliás, parecia haver acerto em seu estudo. As principais estruturas de referência na organização social, tais como presentes no texto "O mal estar na civilização" (1930 [1929]/1969), de Sigmund Freud, paulatinamente, pareciam se deslocar. Novas direções passaram, ainda que de forma muito fresca, a ocupar seu lugar. Novas orientações, novas bússolas (caso ainda faça sentido, chamá-las assim). A ideia de poder estava, enfim, vincada. Talvez nunca tenha estado tão em evidência a intenção e formulação de uma lei mais prazerosa, fragmentada, pontual, itinerante, fluida, evanescente, contraditória e desruptiva à escuta de um sujeito, cada vez menos foracluído da ciência (será?) e, muito provavelmente, cada vez menos foracluído da política.

Em um mundo onde as referências mudam, os deslocamentos - em ampla escala -, ainda que de forma mais ou menos explícita, se tornam inevitáveis. Atualmente, enquanto os pontos de ancoragem pós-modernos se modificam, 
desconjuntamentos se desdobram. A questão que fica, então, é: quais, tão logo, são nossas novas localizações? O que - e como - operam? O que - e como conseguem produzir? Sujeito e (seu) mundo deslizam e se (re)colocam. Narram novas histórias e, especialmente, as narram de modo novo.

Pois sim, com a queda de nosso rei de espadas - ainda que sofrida, ainda que não sem violentas tentativas de reparação, ainda que não sem dilacerantes crises de angústia -, no desencontro da passagem, quando ainda não se sabe muito bem o que se é, talvez, tenhamos, em tempos pós-modernos, um baralho inteiro em nossas mãos.

Vejamos o que é possível se fazer com ele.

\section{Bricolagem}

O processo de escrita deste trabalho foi tão árduo, quanto complexo, vívido e enriquecedor. Aproximar a psicanálise lacaniana das questões pósmodernas fez com que percorrêssemos muitos caminhos diversos. Aproximamonos da narrativa bauminiana e de sua aproximação com a psicanálise freudiana para obtermos certo ângulo para nosso olhar do mundo moderno ao seu pós. Debruçamo-nos em textos de Freud, cujas pontuações são, até hoje, de certo modo, tão atuais. Apoiamo-nos em Alemán e Laclau, acompanhando - e buscando traçar junto - novos desenhos possíveis, agregando à nossa - e, aparentemente, também deles -, questão fundamental: o uso de conceitos da psicanálise que, de fato, nos ajudam a melhor ler, entender e operar, frente a importantes questões da política contemporânea. Escolhemos os seguintes conceitos: solidão comum, significante vazio e ato instituinte. Medulas, fundamentais, de nossa dissertação. Até chegarmos ao último ensino de Lacan, em sua passagem fundamental por seu novo elemento epistêmico-clínico, em seus idos dos anos 1970, a transmissão de seu uso dos nós borromeanos.

De nossa parte, a ideia original caminhava em direção a espaços de diálogo entre certa composição do campo da política - e seus movimentos -, e a possibilidade de uso de algumas ferramentas da psicanálise lacaniana, na intenção de produção de um espaço de trocas e leituras mútuas. Tarefa difícil por, dentre outras questões, tratarem-se de dois campos significativamente vastos e com narrativas, em momentos específicos, um tanto quanto conflitantes. 
Buscamos mergulhar em pontos, então, em que estas duas atmosferas, por si só, poderiam se encontrar, intentando a produção de um campo em diálogo. Esta inquietação, por entender como o mundo de hoje funcionava, nos levou ao encontro de alguns parceiros fundamentais em nossa jornada. O já citado sociólogo polonês Zygmunt Bauman foi um deles. Seus textos nos ajudaram com sua perspicaz leitura do contemporâneo, bem como sua localização, em amplos aspectos, quanto à importância do conceito do tempo na atualidade, em relação a certa corrosão da perspectiva do espaço e, por fím, com sua tentativa de aproximação do psicanalista Sigmund Freud, em sua elaboração conceitual marcadora do lugar da lei e de suas referências em nossos registros modernos e pós-modernos. De delicada importância, foi também o trabalho do psicanalista Dany-Robert Dufour, com sua já delineada aproximação entre os temas da psicanálise e da política, em que aborda sua perspectiva de dessimbolização da vida do homem pós-moderno como uma marcação importante na atual narrativa neoliberal. Dufour fez alguma presença, neste trabalho, em palavra escrita, mas, mais ainda, em palavra lida, subsidiando a nossa leitura sobre a pós-modernidade, de modo complementar a Bauman. Boa parte de suas reflexões seguem, ainda que, em muitos momentos, de forma subliminar, por nosso trajeto. Jean Baudrillard, nosso inquieto, com sua leitura afiada quanto aos usos da técnica e da tecnologia na operação do sujeito pós-moderno, debruçando-se sob certa jogatina entre o real e o virtual, no que chamamos, atualmente, como sociedade de consumo - e, talvez, em uma maior radicalidade, para consumo -, também foi autor de frescor em nosso percurso, sendo utilizado como pano de fundo de algumas das questões desenhadas aqui. Mais adiante, o psicanalista argentino Jorge Alemán e o cientista político Ernesto Laclau nos banham com seus conceitos, já citados, em que psicanálise e política, finalmente, entram, mais diretamente, em diálogo. Sigmund Freud e Jacques Lacan são nossos carros chefes e, talvez, não por mera coincidência, ocupam os intervalos de nossa cadeia de capítulos.

Nossa principal questão? Entender que sujeito é este que cabe, hoje, no mundo. A partir de que fontes ele opera? De quais referências? Quais produtos? Por conseguinte, buscamos entender que mundo é este que pode fazer tanto com que o sujeito seja, definitivamente, excomungado, quanto, especialmente, acolhido - ainda que nunca sem o intervalo tenso entre estas duas possibilidades. 
O tema abraçado - psicanálise e política - não era tema, de imediato, de livre e fácil acesso. O material, como já sinalizado, era inicial, comparado a outras interrogações, dada a secularidade - e, talvez, interesse - de nossa área. Parecia não ser este um namoro muito interessante, até então. Mas diante da incessante produção de novos reais, nossa civilização talvez tenha passado a demandar, cada vez mais, também nosso olhar teórico-clínico. Afinal de contas, também é em boa parte disso que se trata a narrativa pós-moderna: a queda de narrativas únicas e seus respectivos olhares solitários - e solidários. O encontro pelas diferenças; a produção de um comum. Deslocamentos.

Na subida dos Uns sozinhos, como inaugura Jacques-Alain Miller, apenas o amor poderia lhes fazer mediação (2004, sem pág.). Pois é disso que trataremos, então, aqui: também de Eros, como liga, mas, igualmente - e principalmente -, de outras possibilidades de sua formação. Trataremos das localizações de laços, de tranças, de liga, da existência de novas criações e do que se pode - e se quer registrar no nosso/em um novo possível.

Ainda que falemos em perda da posição de exceção que, antes, freudianamente, tudo (nos) organizava, talvez ainda seja um pouco precitado falar na destituição completa do falocentrismo. Aliás, antes disso, talvez tenhamos mesmo que esclarecer, ainda que pontualmente, do que se trata quando falamos de tal queda. A psicanalista Ângela C. Bernardes resgata, por exemplo, as diferenças entre a composição fálica freudiana e o nosso falocentrismo político, do mesmo modo que busca desvincular a função paterna, vinculada a questões gregárias e legais, da lógica cultural do patriarcado que, muito distante da atmosfera de mediação da primeira, vincula-se a práticas de violência e políticas de submissão (2018, sem pág.). Logo, Bernardes pontua que, por queda do falocentrismo, entendemos e nos interessamos, a bem da verdade, pelas deslocalizações da função do pai, enquanto elemento referencial e simbólico fundamental até então. Dentro disso, entendemos, ainda, os deslocamentos dos referenciais coletivos e das passagens conceituais da psicanálise que, aos poucos, deslizam, de uma clínica quase exclusivamente pautada na neurose para, com Lacan, nos aproximarmos dos referenciais que a psicose nos oferta - o que poderemos ver, mais adiante, com as perspectivas de nó borromeano e sinthome. 
É como nos narra também muito bem e nos orienta a psicanalista MarieHélène Brousse, levando em consideração que nossa concepção de falo tem muito mais a ver com sua palavra do que com sua natureza (2018) - talvez seja este um ponto interessante, e exatamente o de que se trata aqui. Não necessariamente, portanto, de queda ou morte - como, aliás, sabemos ser um bom processo de análise -, mas de transformação, deslocamento. Também nessa direção, talvez não seja mais mesmo de falo que se trate, mas, graças ao protagonismo, inclusive da palavra, da boca e da narrativa feminina em vários dos processos de transformação política sobre os quais nos debruçamos aqui - e sobre os quais estamos localizados neste momento -, passe a se tratar mesmo muito mais de fala do que de falo. E, talvez, como Brousse recorda muito bem, nesta mesma direção, seja este muito mais o momento de se substituir o poder dos imperativos pelo do desejo (2018). Este sim muito mais acompanhado de nossa necessária subversão. Acreditamos mesmo não ser necessário muito para compreender, aliás, a aproximação entre feminino e subversão.

Que assim seja e que sobre isso nos debrucemos, em nome da Mãe, da Filha e da Santa. 


\section{Zygmunt Bauman: do moderno à sua pós}

\subsection{Essa tal modernidade: há pessoas fora do quadro}

Por volta de 1950, o sociólogo Zygmunt Bauman ingressa na Universidade de Varsóvia, dando início ao seu percurso profissional até o ano de 1968. Em seguida, dá continuidade a seu trabalho pela Universidade de Tel Aviv e, a partir de 1971, segue para a Universidade de Leeds, no Reino Unido. Bauman morre em 2017, deixando uma obra marcada, especialmente, por sua atenção às disposições das dinâmicas pós-modernas. A partir destas, analisa a função dos paradigmas da pós-modernidade e deslocamentos de seus lugares de poder, seu caráter de representação e, especialmente, o movimento de seus vínculos sociais. É nessa direção que Bauman pontua, também, um antes e um depois que caracteriza a modernidade e sua pós: as localizações - e deslocalizações - do complexo e polêmico território da lei, da ética e, no registro da pólis, das possibilidades dos modos de existência nesses dois territórios e da matemática dos vínculos nesses momentos históricos.

Atento a essas conexões, Bauman localiza pontos fundamentais deste primeiro momento, a modernidade - ou o que vem a nomear como modernidade sólida: "São os tempos do ambiente relativamente estável da "fábrica fordista" (...), o ambiente sólido-moderno em que os "carentes de outro capital" se fixam" (2007b, p. 65). É o cenário da revolução industrial, período marcante do desenvolvimento da cultura capitalista. Cenário em que encontramos a cultura - e a valorização simbólica, narrativa e material - da família tradicional, das identidades significativamente pré-estabelecidas - ou pouco heterogêneas, comparadas às possibilidades da experiência atual. Momento das referências gerais à função do pai, já se impondo, desde o período renascentista - que, aliás, Bauman busca parcialmente materializar via teoria freudiana, como veremos mais adiante -, e das instituições representativas, tais como, de alguma forma e em algum grau, as encontramos até os dias atuais.

A extensão fabril era de larga escala - assim como sua produção. No entanto, os direitos sociais, não sem lutas, mas, a partir delas, eram marcas importantes a serem asseguradas pelo Estado (BAUMAN, 2007b, p. 65). Aliás, trata-se do tempo de saída do trabalho artesão e do campo para o desenvolvimento 
das grandes metrópoles e de seu respectivo adensamento. A partir de tal processo, as cidades também se tornam a morada das, assim chamadas por Bauman (2007b), "organizações sociais", ou seja, das "estruturas que limitam as escolhas individuais, as instituições que asseguram os repertórios de rotinas, os padrões de comportamento aceitáveis" (BAUMAN, 2007b, p. 7). No domínio religioso, o catolicismo passara a ser altamente influenciado, quando não substituído, pelo protestantismo, modificando, assim, ética e etos locais. No âmbito sócio econômico, adensadas as classes, uma luta social marca seus laços - burgueses e proletários dão seu tom. Aliás, as identidades também são vistas como bem estruturadas e demarcadas e a sociedade é vista menos como uma dimensão complexa, em formato de rede (face provável de nossas marcações líquidas atuais), do que como uma estrutura fixa e determinada, "para não falar em uma totalidade sólida" (BAUMAN, 2007b, p. 9). Ou seja, tanto as identidades privadas e íntimas quanto as públicas e coletivas estão, às claras, endereçadas a pontos específicos. Era este mesmo o momento em que

A comunidade de fato defendia sua densa sociabilidade reclassificando prontamente os poucos estranhos que por vezes entravam sua órbita como amigos ou inimigos. Ostensivamente uma estação temporária, a estranheza não apresentava um sério desafio à ordenada e sólida dualidade do mundo (BAUMAN, 1999b, p. 71).

É o cenário positivista da razão, da segurança e da solidez. O ser pesa como chumbo, materializando um contexto, ao menos aparentemente, desenvolvimentista e progressista. Referências, como uma suposta possibilidade de equilíbrio, ganham corpo e estabelecem certa narrativa.

Segundo Bauman, é neste cenário que os significantes beleza, limpeza e ordem orquestram (1998, p. 8). Na leitura mais comumente entendida como subjetiva, seria, na aventura moderna, mais do que em qualquer outro período, que os sujeitos passariam a se localizar como frutos da "atividade cultural" (1998, p. 7). É nesta direção que passam a atuar com referências como a perspectiva do autoconhecimento, resultado da pesquisa de intelectuais e cientistas da época, como o próprio Sigmund Freud (1998, p. 7). 
Em O mal estar na pós-modernidade (1998), Bauman busca o diálogo - e uma atualização crítica - com o texto freudiano quase homônimo, "O mal estar na civilização" (1930[1929]/1969). A partir deste texto, o autor localiza a pontualidade de perspectivas como a do princípio do prazer e de princípio da realidade ou, o que chama, neste momento moderno, de "A troca de um quinhão de felicidade por um quinhão de segurança" (BAUMAN, 1998, p. 8). De caráter regulamentar - e de destaque - neste momento de organização social, seria este, aliás, segundo Bauman, o princípio que imperaria na cartografia moderna e é nessa direção que significantes como renúncia, perdas, ordem, controle, regulações, família e Estado seriam categorias primárias, altamente atuantes.

Trata-se, no lugar moderno, ainda do momento em que se ganha uma coisa e perde outra (BAUMAN, 1998, p. 10). As estruturas, nos mais variados sentidos, são claras. No entanto, "obscuros e monótonos dias assombraram os que procuravam a segurança" (BAUMAN, 1998, p. 10). A composição de Freud de que, segundo Bauman, "a felicidade só seria possível como fenômeno episódico" (BAUMAN, 1998, p. 10) seria, nesta conjuntura, plenamente compreensível. A valorização do equilíbrio entre as partes vigora e se almeja a intenção desenvolvimentista de progresso e perfeição. Intenciona-se abolir a feitura, o ruído e o caos, "as pessoas que estavam fora do lugar, que não se ajustavam, que [o] estragavam" (BAUMAN, 1998, p. 13).

Os dejetos e o imundo não seriam, então, convidados a participar da festa da modernidade. São as identidades locais que são importantes, tal como a referência à perspectiva de igualdade.

Neste momento, a comunidade e o funcionamento da pólis são o que dão o tom à organização social e, logo, às suas respectivas possíveis e desdobradas referências. Os mecanismos legais, para gerarem a ordem, multiplicam-se. Instituições nascem, ratificam-se e proliferam. É a época em que o panóptico foucaultiano faz a metáfora do poder (BAUMAN, 1988, p. 13). Um poder em que a materialidade do espaço, as fixações das localizações e as vigilâncias para uma tentativa de possível não mobilidade imperam. É o período do histórico casamento entre o poder e a política, em que a própria vida comunal é endossada pelo Estado (BAUMAN, 2007b, p. 8). A busca é pelos referenciais de unidade. E 
a sociedade é vista como uma estrutura fixa, com movimentações preferencialmente mecânicas. Trata-se do momento da "sólida rocha da segurança" (BAUMAN, 1998, p. 18). As referências de pensamento, planejamento e ação estão sendo elaboradas em longo prazo (BAUMAN, 2007b, p. 9). Religião, pai e Estado ocupam os referenciais de tomada de decisão. As orientações são mais verticais do que horizontais. Há hierarquia, o valor da sabedoria e da transmissão. Os movimentos estão, culturalmente, bem definidos, codificáveis, repetitivos. $\mathrm{O}$ ar de rotina aborda as marcas de seu tempo.

Armado com essas receitas, sinto-me seguro. Para a maior parte das coisas que faço, e para todas as que faço rotineiramente, elas oferecem um guia suficiente e de confiança. Elas têm todo "o aspecto de uma suficiente coerência, clareza e solidez para dar a qualquer pessoa uma oportunidade razoável de compreender e ser compreendida" (BAUMAN, 1998, p. 18).

Toda essa segurança, no entanto, não nos é ofertada sem a óbvia crítica bauminiana e sem os terremotos que um estranho, no campo das certezas, pode causar em espectros de intolerância e rejeição.

Só ostentam, porém, essa qualidade saudável e maravilhosa porque são "evidentes", prosaicamente aceitas, sem muita reflexão - e essa despreocupada situação só pode existir desde que ninguém ao redor comece a colocá-las em dúvida, pergunte sobre seus fundamentos e razões, ressalte as discrepâncias, exponha a sua arbitrariedade. É por isso que a chegada de um estranho tem o impacto de um terremoto (BAUMAN, 1998, p. 18).

Certo e errado, normal e anormal, ricos e pobres: todos estão claramente localizados. O território define. As definições de tempo e espaço são compreendidas com exatidão. Os governos estatais são protagonistas: "a separação e o eminente divórcio entre o poder e a política" (BAUMAN, 2007b, p. 8) ainda não dão o tom. Busca-se que os registros dos bens - e também dos corpos - sejam realizados. "Na ordem harmoniosa e racional prestes a ser constituída não havia nenhum espaço - não podia haver nenhum espaço - para os "nem uma coisa, nem outra"”' (BAUMAN, 1998, p. 28). 
Espera-se que todos estejam devidamente assegurados. Relações são criadas para durar e, se tempo e espaço entrassem em competitividade, o segundo sairia, com toda certeza, triunfante.

A história é, aqui, personagem detentora de localidade - e de valor fundamental. E a história da vida ainda não foi sistematicamente subdividida em uma série de episódios um tanto quanto confusos (BAUMAN, 1998, p. 36).

Enfim, na passagem de seu percurso, Bauman traça sua imagem do moderno para a circunscrição do que lhe é oposto (ou abarca seus deslocamentos). Apresenta, primeiro, esta cartografia: o registro das identidades pouco permeáveis pela diversidade de escolhas mais particulares, um estado que marca lugares mais precisos, emblemáticas instituições centralizadoras, o lugar de líderes representativos e $(\mathrm{m})$ lugares de fala exclusivos.

Entoa-se o que Bauman nomeia como os locais (BAUMAN, 2003b, p. 275) em oposição aos nômades (BAUMAN, 2003b, p. 273), ainda por vir. Tudo isso faz com que os campos dos sujeitos, mais ou menos internos, ganhem uma determinada fotografia. Cena que, claramente, decompõe-se e se modifica no cenário que lhe segue.

É este mesmo o momento em que o objetivo era o de que nada saísse do (en)quadro(e).

\subsection{Pós-modernidade: um rei caolho ou os insones - um quinhão de segurança por um quinhão de liberdade}

Mais frequentemente estas são coisas móveis, coisas que não se cravarão no lugar que lhes é designado, que trocam de lugar por sua livre vontade. A dificuldade com estas coisas é que elas cruzarão as fronteiras, convidadas ou não a isso. Elas controlam sua própria localização, zombam, assim, dos esforços dos que procuram a pureza 'para colocarem as coisas em seu lugar' e, afinal, revelam a incrivel fraqueza e instabilidade de todas as acomodações. Baratas, moscas, aranhas ou camundongos, que em nenhum momento podem resolver partilhar um lar 
com seus moradores legais (e humanos) sem pedir permissão para isto.

Zygmunt Bauman, Modernidade e ambivalência

$\mathrm{Na}$ busca por uma fotografia da sociedade pós-moderna, o sociólogo Zygmunt Bauman traz, então, sua engenharia da modernidade líquida. Estando já, ao menos de forma introdutória, localizados nos traçados do mundo moderno, visualizemos um pouco, então, o que o autor desenvolve sob este nome.

Segundo Bauman, na lógica pós-moderna, há uma importante mudança, e é o princípio de realidade que tem passar a se defender "no tribunal de justiça onde o princípio de prazer é o juiz que está presidindo" (1998, p. 9). Aqui, questões como a liberdade individual são fundamentais. É esta a responsável por dar peso e valor a todas as outras dimensões da vida social. É ela a mestra das referências de avaliação, definindo normas e medidas gerais. Segundo Bauman:

\begin{abstract}
Isso não significa, porém, que os ideais de beleza, pureza e ordem que conduziram os homens e mulheres em sua viagem de descoberta moderna tenham sido abandonados, ou tenham perdido um tanto do brilho original. Agora, todavia, eles devem ser perseguidos - e realizados - através da espontaneidade, do desejo e do esforço individuais (BAUMAN, 1998, p. 9).
\end{abstract}

Espera-se que todos estejam devidamente assegurados. Relações são criadas para durar e, se tempo e espaço entrassem em competitividade, o segundo sairia, com toda certeza, triunfante. Aqui, o eterno mais prazer - modo de funcionar considerado, em tantos outros momentos da história, como autodestrutivo e altamente perigoso - parece se tornar a direção mais almejada.

Para Bauman, a lógica dos traçados pós-modernos tem a ver com uma diversidade de elementos, diante dos quais, um se acentua: a mudança política para a perspectiva global $(2007 b$, p. 14). A insegurança se torna sinônimo da invenção das cidades. Práticas de violência cada vez surgem de formas mais amplas e com posturas mais radicais. São responsivas aos choques entre as identidades locais e os poderes globais. Verdadeiros campos de batalha explodem. Não à toa, seria o medo o mote da nova política. Sentimento estratégico que se multiplica em um piscar de olhos. Não coincidentemente, ainda, é também na pós- 
modernidade em que há o divórcio entre o poder e a política - dupla instituída e presente desde o Estado Moderno e, até recentemente, na fundação do EstadoNação.

Enquanto uma referência de poder global toma espaço, uma política local tenta permanecer e, segundo nosso autor, definhar. São o mercado, as iniciativas privadas e os atos individuais que entram, prioritariamente, em cena. A competição dá o tom do que antes se chamava colaboração. A marca seria a da divisão:

“(...) condição de estratagemas temporários que precisam ser suspensos ou concluídos no momento em que se esgotarem suas vantagens. (...) A sociedade é cada vez mais (...) tratada como uma rede (...), percebida e encarada como uma matriz de conexões e desconexões aleatórias e de um volume essencialmente infinito de permutações possíveis" (BAUMAN, 2007b, p. 9).

Toda nossa organização parece se tratar de uma série de projetos e episódios de curto prazo. As orientações passam a ser mais laterais do que verticais. E nosso design de organização ocorre de forma especialmente fragmentária.

Cada passo seguinte deve ser uma resposta a um diferente conjunto de oportunidades e a uma diferente distribuição de vantagens, exigindo, assim, um conjunto diferente de habilidades e um arranjo diferente de ativos (BAUMAN, 2007b, p. 9).

A responsabilidade do indivíduo é extrema. Não há mais história, nem transmissão. A maior virtude é a “(...) flexibilidade, a prontidão em mudar, rapidamente, de táticas e estilos (...) buscar oportunidades mais de acordo com sua disponibilidade atual (...)" (BAUMAN, 2007b, p. 10).

A estrutura pós-moderna seria, fundamentalmente, amarrada através de um ponto crucial: uma hipervalorização da dimensão de mobilidade (BAUMAN, 1998, p. 114). Mobilidade dos líquidos, dos nômades, dos valores, das referências. Mobilidade da moldabilidade. Da plasticidade. "O nome do jogo é mobilidade: a pessoa deve poder mudar quando as necessidades impelem - ou os sonhos o solicitam" (BAUMAN, 1998, p. 114). 
E a liberdade de movimento seria, curiosamente, nosso principal elemento estratificador:

Essa aparente autossuficiência é, evidentemente, apenas uma ilusão, tal como no caso dos outros numerosos mecanismos que anunciam o milagre do movimento perpétuo capaz da autopropulsão e da auto nutrição (BAUMAN, 2007b, p. 1516).

Aliás, a liberdade de movimento seria nosso novo centro moderno, e tudo no entorno se transformaria a partir dela. A própria dimensão da lei, até então inabalável, aos poucos, se dilui. Passaríamos das leis aos deleites. A lei poderá ser apreciada - e escolhida - individualmente. Mesmo nas representações ainda institucionais que nos restam, lei e ordem se traduzem no cenário da segurança pessoal, quiçá, corporal (BAUMAN, 2007b, p. 18). Caracterização central que daria, a bem da verdade, nova localização a todas as definições sociais, psicológicas, culturais, mais ou menos fundamentais, mais ou menos estruturais até então.

Os estágios sucessivos das guerras modernas deslizariam entre as comunidades planetárias. São os proprietários ausentes, das elites globais. Aliás, tratar-se-ia mesmo da guerra entre os territoriais e os não-territoriais (BAUMAN, 2007a, p. 284). Esta é a formulação que daria o tom. Estas seriam as guerras modernas, marca fundamental, da engenharia dos nossos novos laços.

As mudanças na atmosfera do poder parecem estar claras. Resta-nos saber quais são as operações possíveis, a partir destas e a partir de então.

Como desdobramento desta nova configuração moderna, teríamos, na mesma frequência, a insegurança dos bens e dos corpos. O medo é carro chefe das sociedades modernas e das cidades que se aninham, "Mas é a insegurança do presente e a incerteza do futuro que produzem e alimentam o medo mais apavorante e menos tolerável" (BAUMAN, 2007b, p. 32). Insegurança e incerteza que nascem do sentimento de impotência:

(...) parecemos não estar mais no controle, seja individual, separada ou coletivamente, e, para piorar ainda mais as coisas, faltam-nos as ferramentas que possibilitariam alçar a política a um nível em que o poder já se estabeleceu, 
capacitando-nos assim a recuperar e reaver o controle sobre as forças que dão forma à condição que compartilhamos, enquanto estabelecem o âmbito de nossas possibilidades e os limites à nossa liberdade de escolha (BAUMAN, 2007b, p. $32)$.

Derrete-se a segurança e todos os seus sólidos subsequentes.

Uma vez disfarçado e não mais um vetor, não mais uma seta com um indicador, ou um fluxo com uma direção, o tempo já não estrutura o espaço. Consequentemente, já não há "para frente" ou "para trás"; o que conta é exatamente a habilidade de se mover e não ficar parado (BAUMAN, 1998, p. 113).

No não-movimento: o obscuro. É o que encontrávamos na segurança e no plano da razão. No entanto, levando em consideração a própria deseternidade da felicidade, deparamo-nos, hoje, com nova frente: "Se obscuros e monótonos dias assombraram os que procuravam a segurança, noites insônes são [então] a desgraça dos livres" (BAUMAN, 1998, p. 10).

Em tempos pós-modernos, o rei caolho é a espacialidade do líder. O líder, aliás, é tão especialmente humano, especialmente comum, que acaba por dissolver seu próprio trono. A liberdade, esta sim, é rainha. Fotografa as linhas e costuras do mundo pós-moderno. Resta-nos saber o que se pode costurar com ela em transcrições possíveis. Nossa aposta é a de que nos sirva para além de alimento à babel; que nos sirva a perturbar, positivamente, o cenário, para além de seu estado de insegurança e insônia, ainda que não sem eles. Vejamos o que mais poderemos pensar nesta direção.

\subsection{Uma necessária ordem para borrar o caos}

Em 1998, Bauman publica $O$ mal estar na pós-modernidade, em que disserta sobre o trabalho quase homônimo, de Sigmund Freud, "O mal estar na civilização" (1930[1929]/1969). Sobre o este texto, Bauman diz:

[seria] sob este título que o provocador desafio de Freud, ao folclore da modernidade, penetra[ria] em nossa consciência coletiva, modelando, assim, 
nossos pensamentos a propósito das consequências - intencionais e não intencionais - da aventura humana (BAUMAN, 1998, p. 7).

Para Bauman, os estudos de Freud, com o resultado de suas novas análises, teriam papel fundamental - e, diga-se de passagem, bastante transgressor -, no desenvolvimento do homem e da civilização modernos. Dois apontamentos de Bauman sinalizam sua ideia de civilização. Na primeira, o sociólogo pontua: "A civilização é uma ordem imposta a uma humanidade naturalmente desordenada" (1998, p. 8). Na segunda, diz que "A sociedade é um compromisso, uma troca contínua e para sempre instigada a se renegociar" $(1998$, p. 8$)$.

Sobre nossa civilização atual, no entanto, Bauman diz que, sendo o século XXI substancialmente distinto do XX,

(...) estamos em um momento de interregno (...) [E] No "interregno" não somos uma coisa nem outra. (...) as formas como aprendemos a lidar com os desafios da realidade não funcionam mais. As instituições de ação coletiva, nosso sistema político, nosso sistema partidário, a forma de organizar a própria vida, as relações com as outras pessoas, todas estas formas apreendidas de sobrevivência no mundo não funcionam mais direito. Mas, [no entanto], as novas formas de substituir as antigas ainda estão engatinhando (BAUMAN, 2011). ${ }^{2}$

Trata-se das quedas das referências ainda sem substituição a priori.

O filósofo Robert Dufour define no texto "A política da cidade" (2016) sua concepção de política: “(...) a constituição e administração de uma comunidade de humanos, que vivem juntos, em um território determinado" (2016, sem pág.). A concepção, embora simples, é, do mesmo modo, ampla o suficiente para servir para pensarmos nossas atuais relações interpessoais e, especialmente, suas dimensões de poder. Neste texto, Dufour nos lembra que a palavra Cité se denomina, em grego, pólis, o termo que esculpe o nome política e apresenta a clara vinculação amalgamada destas duas atmosferas. Mais do que isso, em uma direção que se aproxima, significativamente, da narrativa do Édipo freudiano, Dufour nos lembra da importância de um recorte de lei para a fundação das primeiras cidades democráticas, que se estabeleciam pela proibição da pleonexia. Dito de outro modo, pela proibição do desejo de se querer sempre mais - o que

\footnotetext{
${ }^{2}$ Transcrição do trecho compreendido entre o minuto 2:29 e 3:12 do vídeo citado.
} 
pode nos lembrar, também, um certo "mais além" e do excesso edípico que, por mais que se quisesse se livrar do pai castrador, permaneciam as bordas do pai morto.

Da pleonexia de Dufour ao Édipo de Freud, Gustavo Dessal nos organiza quanto ao recorte bauminiano de nossa atual civilização, considerando que o conceito de liquidez é o significante com o qual Bauman irá depurar o real de um mundo que, a partir da lógica da pós-modenridade, fica órfão de sua estrutura narrativa e passa a ter que "reinventar sua trajetória parcial ou pagar o terrível preço do desterro para o não mundo" (BAUMAN; DESSAL, 2017, p. 12).

Há, então, que se reinventar. Mas como? Com o que? E a partir de quais paradigmas?

O coletivo é, assim, para Bauman, já nos tempos modernos, marca fundamental de um processo de resistência ao obscurantismo e à monotonia da era da performance da exatidão. Mais especificamente, aproximaríamos o coletivo à sua ideia, aqui, de comunidade. “Ao contrário da opinião já amplamente aceita, é a proteção (o seguro coletivo contra o infortúnio individual), e não a redistribuição de riqueza que está no cerne do "Estado social"” (BAUMAN, 2007b, p. 65) - a busca por administrar o medo.

$\mathrm{Na}$ extensão do pós-moderno, Bauman continua com sua aposta sobre o coletivo, ainda que se julgue incapaz de já definir sua natureza e orientação. De todo modo, continua: "a proteção [só] pode ser coletiva ou nenhuma" (BAUMAN, 2007b, p. 65).

Segundo Bauman, a pós-modernidade vive do irregular. Um irregular que torna, ainda, tudo mais fácil de governar (2007b, p. 99). Assim, sabemos, então, que alguma regra e regularização se tornam necessárias. Restar-nos-ia saber quais e como estas deveriam funcionar. Freud, em "O mal-estar na civilização" (1930[1929]/1969), também faz essa mesma pontuação. Remédio contra a sempre possível e presente expressão da barbárie. Fica o questionamento quanto à justa medida dessa regularização, sempre deslizante para seu oposto, sempre tendo que ser recolocada e (re)discutida a partir de referências coletivas. Estas, significante fundamental em toda marcação bauminiana, como já dito, para um possível da 
civilização em contrassenso subversivo da vida única, exclusiva e individual. A vida, enfim, como lugar onde não há exceções porque todos desejam sê-lo.

Se vier a existir uma comunidade no mundo dos indivíduos, só poderá ser (e precisa sê-lo) uma comunidade tecida em conjunto a partir do compartilhamento e do cuidado mútuo; uma comunidade de interesse e responsabilidade em relação aos direitos iguais de sermos humanos e igual capacidade de agirmos em defesa desses direitos (BAUMAN, 2003a, p. 134).

Ainda sobre o fundante lugar dos coletivos, Bauman pontua sua aposta, ainda que sem a negação de suas incertezas:

E o seu esforço pode ser apoiado pela consciência da ligação íntima (e não da contradição!) existente entre o cidadão autônomo, moralmente independente e autogovernado (e por isso muitas vezes indisciplinado, pouco contemporizador e incômodo), por um lado, e uma comunidade política de pleno direito, capaz de auto-reflexão e de se corrigir a si própria, por outro. Os dois termos só podem comparecer juntos, e cada um deles é impensável sem o outro (BAUMAN, 2007a, p. 292).

A questão que Bauman pontua é sobre $o$ que se deve renegociar. A dicotomia "segurança versus liberdade" talvez não seja nossa melhor aposta. Talvez seja mesmo, aliás, o mais terrível dos engodos. A centralidade da questão da segurança recairia sempre, não coincidentemente, sobre os menos abastados, imigrantes e trabalhadores de base. A centralidade da questão do mal-estar teria, no entanto, outra morada: as dimensões da ratificação da seguridade do direito de se ter direitos e a dimensão de igualdade (equidade, até tal alcance) - valores estes a serem pautados, coletivamente, como única maneira de sobrevivermos.

Bauman propõe a leitura de que, na Era Moderna, o Estado coincidiria com o Outro (escreve desta maneira, se aproximando, talvez, também de nosso Outro lacaniano), que asseguraria leis e direitos, amarrados com sua única função: a dimensão da ética (BAUMAN, 1998, p. 69). Hoje, no então, teríamos que apostar em outras seguridades. A defesa de uma espacialidade coletiva e o lugar dos debates e do posicionamento intelectual seriam, segundo o autor, dois pontos fundamentais a serem desdobrados. Nunca pareceu ser tão pouco imaginário e tão encarnado na dimensão humana nossa perspectiva de defesa e continuada 
existência, no cuidado de fazermos frente à inversão da dimensão sartriniana ${ }^{3}$, tão presente na atualidade: "não existem, senão, catástrofes naturais" (BAUMAN, 1998, p. 73), em um radical processo de alienação e desresponsabilização de nossa condição.

Quanto a este ponto fundamental em sua obra - o lugar do intelectual na atual espacialidade pós-moderna -, Bauman destaca a necessidade de sair também do encapsulamento dos registros do status quo, imensamente sedutores: “(...) e coragem é uma qualidade que os intelectuais, outrora famosos por seu radicalismo estrepitoso, perderam na busca de seus novos papeis e "nichos" como expertos, pesquisadores acadêmicos ou celebridades da mídia” (2003a, p. 113).

O autor se apoia no fato de tal classe estar tão submersa no registro da atualidade, como qualquer outra:

(...) com os poderes econômicos cada vez mais extraterritoriais, com uma sociedade que cada vez mais envolve seus membros no papel de consumidores e não de produtores e com a modernidade cada vez mais fluída, "líquida", "desregulamentada". (BAUMAN, 2003a, p. 11).

Dentro de tal percurso, dois paradigmas poderiam nos trazer riscos específicos:

(...) duas emergem como explicações plausíveis de espetacular carreira da "ideologia do fim do mundo". A primeira é o desengajamento como nova estratégia do poder e da dominação; a segunda - o excesso como substituto de hoje para a regulamentação normativa. (BAUMAN, 2003a, p. 113).

Localizar-se nisso, também jogado na espessura desconfortável do mundo líquido pós-moderno, seria papel fundamental, também, do intelectual, partindo para duas narrativas fundamentais: a ordem do universal e a produção do lugar comum, em que ambos se desdobrariam em duas perspectivas - a de uma base igual, para se fazer escolhas, e a das próprias escolhas. Com a queda do contrato social, apoiada pelo livre mercado atual, tal posicionamento seria fundamental, já que, de qualquer forma, algum contrato continuaria se fazendo necessário - única maneira de não termos, como única desopção, o habitat da barbárie.

\footnotetext{
3 "Não existem coisas como desastres naturais" (SARTRE, Jean-Paul apud SALLENAVE,
} Danièle, 1995, sem pág. Tradução nossa). 
Nesta direção, Bauman nos acomoda, também, na pontualidade freudiana:

Os prazeres da vida civilizada, e Freud insiste nisso, vêm em pacote fechado com os sofrimentos, a satisfação com o mal-estar, a submissão com a rebelião. A civilização - a ordem imposta a uma humanidade naturalmente desordenada - é um compromisso, uma troca continuamente reclamada e pra sempre instigada a se renegociar (BAUMAN, 1998, p. 8).

Parece ser, atualmente, um momento mesmo de renegociações.

Por fim, Bauman pontua uma das vantagens da política pós-moderna: a ausência de intencionalidades perfeitas, de estratégias certeiras, de garantias. Observa-se precária, fragmentada e infinita em sua materialidade e existência, mas não em seus múltiplos caminhos e variadas possibilidades (BAUMAN, 1998, p. 256-257).

Nós, psicanalistas, de nossa parte, somos bons em inacabados, não-todos, marcas, pontualidades, sistemas que se compõem no a cada vez. Não os entendemos como fraqueza, mas como contingência fundamental, aliás - é esta mesmo nossa sofisticada contingência do possível.

Quando Bauman traz elementos de Freud para seu questionamento sobre a modernidade, de modo a deslocar o sujeito dessa espacialidade, o sociólogo permanece na desordem mais atual de nossa era pós-moderna, buscando planícies que apoiem modos de vivência que não se reduzam ao mero caos, mas, ao contrário, definam novas formas de análise para localizar a atmosfera e possibilidades de nossos vínculos humanos. Intentando, então, uma transgressão de um cenário convidativo à possível indiferença e ao extremo individualismo, Bauman retoma a implicação e a aposta nas referências coletivas, não acabadas, feitas a cada vez, como dinâmicas fundamentais para a existência humana. Assim, é ela que esculpe pólis, política e nossas possibilidades. Que a implicação responsiva e os constructos coletivos sejam, então, algumas de nossas novas, dialógicas e possíveis bricolagens. 


\section{Enlaçando: Freud e o laço social}

\subsection{Totem e tabu: a matriz do laço social}

Nos anos de 1913 e 1914, o pai da psicanálise, Sigmund Freud, publica seu célebre texto, "Totem e Tabu". Este escrito nos leva a entender esta estranha relação com o mundo inteiro, bem como com o externo: a marca inicial das instituições, as dimensões do laço, as localizações sociais da lei e da ordem.

O totemismo (...) é algo estranho aos nossos sentimentos contemporâneos - uma instituição social-religiosa que foi há muito relegada como realidade e substituída por formas mais novas. Deixou atrás de si apenas levíssimos vestígios nas religiões, maneiras e costumes dos povos na atualidade (...). Os processos sociais e técnicos da história humana afetaram os tabus muito menos do que os totens. (FREUD, 1913-1914/1969, p. 18).

Transformados, mas não desaparecidos, os totens muito simbolizariam e se desdobrariam, por nossas experiências representacionais, rememorando - e atualizando - “(...) um primitivo estágio de nosso próprio desenvolvimento" (FREUD, 1913-1914/1969, p.2 0). O totem, no entanto, tem sua arquitetura toda muito bem desenhada por dois fenômenos, amplamente explicados por Freud: o lugar da exceção e o mito edípico do incesto. Recortes de chefes, líderes, pais e referências (totêmicas) em torno dos quais tudo se organiza.

É o que o psicanalista Paul-Laurent Assoun chama de uma aliança social que tem início em um ato violento, o assassinato do pai, importante balizador para nosso modo de organização que, a partir de tal mito, se desdobra. Sobre isso, o psicanalista discorre, em entrevista a Cristina Lindenmeyer: “(...) o pai foi morto e agora criamos e recriamos ideais. Quer dizer, o pai morto, nós o fazemos reviver em permanência, mas sob um fundo de ambivalência" (LINDENMEYER, 2018, p. 436).

Ou seja, tanto a formação individual, quanto a estruturação social caminham de modos estreitamente ligados. A divisão "sujeito versus sociedade", que vemos ainda em distintas áreas do saber, até os dias de hoje, já era baliza de críticas em tempos freudianos. É nestes resquícios e atualizações que Freud também faz uma importante aproximação a outro campo de estudos - a antropologia social -: 
(....) uma comparação entre a psicologia dos povos primitivos, como é vista pela antropologia social e a psicologia dos neuróticos, como foi revelada pela psicanálise, está destinada a mostrar numerosos pontos de concordância e lança nova luz à fatos familiares às duas ciências (FREUD, 1913-1914/1969, p. 20).

Freud estrutura sua tese com base nos aborígenes da Austrália, considerados representantes das tribos selvagens mais antigas e simplórias que, sem abrigos fixos, cultivo do solo ou domesticação dos animais, não possuíam reis nem chefes individuais, mas todos seus assuntos eram tratados em um conselho de anciães que já estabeleciam o tabu do incesto como instrumento central para sua organização social, enlaces possíveis, limitações demarcadoras (FREUD 1913-1914/1969, p. 20-21). O totem, por sinal, seria, por definição, exatamente isso: um elemento qualquer que estabeleceria relação peculiar com todo o clã, atribuindo-lhe determinados formatos, vicissitudes, demarcações. O clã fica sujeito a obrigações para com o totem, enquanto o mesmo tem, para com o clã, uma resposta de auxiliar e guardar (FREUD, 1913-1914/1969, p. 21).

Normalmente, o totem era herdado pela linhagem feminina e recebia a função de base de todas suas obrigações sociais, sobrepondo-se às relações consanguíneas. Este também não estaria vinculado a um lugar qualquer, mas distribuído por todos os espaços ocupados por seu clã (FREUD, 1913-1914/1969, p. 21-22). Segundo Freud, "muitos investigadores tendem, assim, a encará-lo como uma fase necessária do desenvolvimento humano (...) universalmente atravessada" (1913-1914/1969, p. 22).

Curiosamente, certa descentralidade, revelada pelos totens, demarcadores específicos de cada tribo, ligados mais a um objeto pontual e à linhagem feminina, do que a um ser específico, como um pai, um líder ou um Deus universal, nos aproxima e lembra, de forma inesperada, de nossos marcadores pós-modernos; de habitantes cada vez mais nômades e cada vez mais distantes, novamente, de fronteiras fixas. Trata-se de uma suposição a ser melhor investigada.

Paul-Laurent Assoun pontua que "Totem e Tabu" (1913-1914/1969) nos serve como importante baliza, ao longo de toda a história, para observarmos as possíveis mudanças em nossos fenômenos sociais ou no que Lacan chama de discurso (LINDENMEYER, 2018, p. 433). De qualquer forma, "Totem e Tabu" 
se utiliza destes marcadores, atravessando-os e trazendo-os até o campo da estrutura social.

A aproximação de Freud dos campos classicamente sociológicos e a psicanálise foi tema mais ou menos presente, aliás, em várias das análises que conduzia. Ainda que "Totem e tabu" represente "(...) uma primeira tentativa de aplicar o ponto de vista e as descobertas da psicanálise a alguns problemas não solucionados da psicologia social (...)" (FREUD, 1913-1914/1969, p. 5), a ideia era diminuir a distância entre os estudos sociais e o campo da psicanálise. Segundo Freud, “(...) uma contribuição ocasional entre ambas não poderá[ria] deixar de ser proveitosa para a pesquisa" (1913-1914/1969, p. 6).

Mas o que são, então, totens e tabus, e como estes poderiam se encontrar na espacialidade contemporânea? Como poderiam nos servir nos tempos atuais?

Tanto as marcas dos povos primitivos, com seus métodos, quanto de nossa tenra infância, com seus modos, fariam, segundo Freud, parte de nossas vidas contemporâneas. Sejam estas em âmbito mais ou menos coletivo ou mais ou menos íntimos e privados, ofertariam, à contemporaneidade, contornos, localizações, estruturas. Segundo Wihelm Wundt, aliás, o tabu seria o código de lei não escrito mais antigo da humanidade, como relembra Freud. (19131914/1969, p. 19). Como código de interdição e simbolizações, com certeza o tabu é um de nossos códigos civilizacionais.

$\mathrm{Na}$ marca mítica sustentada por Freud com o registro da exceção, do assassinato do pai, inaugura-se o tempo civil dos habitantes humanos, ou seja, o tempo onde passamos a (co)existir como uma organização social em torno de tal fato. Assim, organizar-se-ia uma determinada crença que constituiria laço e organizaria seu entorno. Pela fé no simbólico, uma estabilização. Seria o fantástico do parricídio originário, estabelecendo nossos limites e possibilidades e nossas condutas desdobradoras. Após a morte do pai, seu registro organizador permanece, mantendo a verticalização da ordem e o lugar de exceção do líder travestido, agora, em um pai morto. Assim, para Freud, o tabu seria mesmo “(...) a raiz de nossos preceitos morais e nossas leis" (1913-1914/1969, p. 23).

Nem o medo, nem os demônios podem ser considerados (...) como as coisas 'mais primitivas', impenetráveis a qualquer tentativa de descobrimento de seus antecedentes. A coisa seria diferente se os demônios realmente existissem. Mas 
sabemos que, como os Deuses, eles são criações da mente humana, foram feitos por algo e de algo (FREUD, 1913-1914/1969, p. 23).

É nas descobertas que estabelecem estes laços ou estes algos, nossas simbologias, medos, necessidades, interdições e, logo, na definição de nossa espacialidade possível que, desde sempre, segundo Freud, articularíamos o público e o privado, o sócio e o indivíduo ou o que, em outras palavras, poderíamos apresentar como as inevitáveis marcas do sujeito na montagem de sua arquitetura, também social e também concreta e institucional. Como diz Assoun, é a libido que está em jogo em "Totem e Tabu" (LINDENMEYER, 2018, p. 436). Logo, é por seus desdobramentos que o sujeito monta seus cenários tanto internos quanto externos.

Desse modo, na suposta falência da autoridade simbólica na atualidade ou de sua escansão, seu deslocamento em repertórios mais múltiplos e menos totalitários -, nossos ideais, enquanto referências específicas, diminutas, parecem estar perdendo um pouco de seu valor. No entanto, o desejo permanece para fazer liga e para compor laço; resta-nos saber a partir de quais marcações.

Resta-nos saber quais são os laços que nos enlaçam hoje. Quais são as estruturas, seus registros, seus totens? Quais são seus tabus (caso haja algum)?

Se a lei que organiza não vem mais de um, é possível que ela se inaugure a partir de vários? E isso ainda a nomearia enquanto lei?

"Totem e Tabu" traz, então, na via da psicanálise, uma possível matriz para o laço social. O que desagua na quase totalidade das instituições que marcaram e organizaram nossa dimensão humana, em registro coletivo e, sistematicamente, cultural. Trata de como nos relacionamos com nosso mundo interno e com os outros, por via da operação de um elemento fundamental que organiza toda a horda. Com os desdobramentos e experiências civilizacionais, no entanto, até as raízes mais fundamentais estariam aptas a deslocamentos. A submissão a um referencial de autoridade e a suposição de, como diz Regina Herzog, "uma referência universal com relação ao modelo de subjetividade proposto" (2002, p. 51), a nosso ver, parecem ser vistas, na atualidade, como "o grande problema [que] reside no fato desse ponto de referência ser pensado como absoluto, comportando o sentido de único" (HERZOG, 2002, p. 51). Propomos 
que seja, então, desta crítica que se trata a inflexão da nossa composição dos novos laços sociais e suas respectivas instituições pós-modernas.

Freud pensou, com extrema habilidade, as marcações de nossa civilização moderna. Cabe-nos enriquecer nossa análise, agora, inclusive a partir de suas referências, mas também com os devidos deslocamentos que, na pósmodernidade, fazem com que funcionemos partir de outros e novos parâmetros.

Vejamos.

\subsection{Psicologia das massas e análise do eu: o outro social e o lugar do líder}

A oposição entre a psicologia individual e psicologia social ou das massas, que à primeira vista pode parecer muito significativa, perde boa parte de sua grandeza se a examinarmos mais detidamente.

Sigmund Freud, Psicologia de Massas e Análise do Eu

É em 1921 que o texto "Psicologia das massas e análise do eu" é publicado por Sigmund Freud, estabelecendo uma dimensão essencial de aproximação entre as esferas individuais e coletivas. Quanto a isso, o autor disserta:

É certo que a psicologia individual se dirige ao ser humano particular, investigando os caminhos pelos quais ele busca obter a satisfação de seus impulsos instintuais, mas ela raramente, apenas em condições excepcionais, pode abstrair das relações deste ser particular com os outros indivíduos (FREUD, 1921/2011, p. 10).

Qualquer relação cotidiana com um outro social - pai, mãe, médico, professor, policial - segundo Freud, é classificada como fenômeno social e, exatamente deste lugar, contribui como elemento fundamental na constituição do indivíduo (1921/2011, p. 10).

Em "Psicologia das massas e análise do eu" (1921/2011), Freud se debruça sobre a composição dos grupos, na direção do estabelecimento do vínculo entre 
seus membros e de como se compõe o lugar do líder como representação e direção. Quanto a isso, o psicanalista questiona do que se trata, então, um grupo, e como este adquire a capacidade de exercer influência tão decisiva sobre a vida mental do indivíduo.

Especialmente o lugar do líder ocuparia, aqui, função, então, fundamental. Codificaria a organização do grupo, estabeleceria seu código de lei, ratificaria seus interditos. Representaria o centro de todos os desdobramentos que se seguiriam.

Os ideais administrariam o cenário entre líderes e liderados. O domínio faz morada na crença de que este, o líder, sabe o que diz. O líder "Paralisa toda a nossa capacidade crítica e nos enche de espanto e respeito. Provocaria um sentimento semelhante ao do fascínio na hipnose" (FREUD, 1921/2011, p. 22). Há um “encanto magnético" (FREUD, 1921/2011, p. 22) que estabelece o líder como núcleo de tudo que se desdobra. Ele é o referencial.

Durante a leitura do texto freudiano, seja no caso dos líderes, seja no dos outros que ocupam nossa cena cotidiana em parcerias em maior ou menor escala, observamos que se desenvolve, então, a dimensão da importância do lugar do outro em nossa composição individual: "Na vida psíquica do ser individual, o outro é, via de regra, considerado enquanto modelo, objeto, auxiliar e adversário e, portanto, a psicanálise individual é, também, desde o início, psicologia social (...) (FREUD, 1921/2011, p. 10).

Freud complementa:

As relações dos indivíduos com seus pais e irmãos, com o objeto de seu amor, com o professor, seu médico, isto é, todas as relações que até agora foram objeto privilegiado de pesquisa psicanalítica, podem reivindicar ser apreciados como fenômenos sociais (FREUD, 1921/2011, p. 10).

Para Assoun, quando Lacan diz que a fala é a fala do Outro, este apenas acentua o que Freud já apresentava quanto à constituição do sujeito (LINDENMEYER, 2018, p. 432). Para Freud, a base sociológica não poderia ser feita sem os primeiros vínculos sociais do sujeito (1921/2011, p. 10) e, deste 
modo, pensar em um desvinculamento dessa ordem, a posteriori, seria prática, no mínimo, estranha e questionável.

É por este caminho que o autor aborda, por exemplo, a obra Psicologia das Multidões (1895), de Gustave Le Bon, a título de entender mais sobre a influência das massas sobre o indivíduo - mas, igualmente, visando a compreender sua direção contrária. Aproxima-se, assim, do conceito de alma coletiva, apresentando a amarração distinta dos atos coletivos e individuais, o estado provisório da massa psicológica e sua composição heterogênea que “(...) por um instante se soldaram (...)” (FREUD, 1921/2011, p. 13). Um “(...) inconsciente comum a todos [que] é posto a nu (...)" (FREUD, 1921/2011, p. 14). Os laços que se compõem, aqui, segundo Freud, funcionam sem a base em um certo medo que media, mas apenas de forma “(...) impulsiva, volúvel, excitável” (FREUD, 1921/2011, p. 18).

De qualquer forma, algo ligaria estes indivíduos. Mas o quê? Uma das suposições curiosas de Freud se referencia a um aparente rebaixamento da crítica dos humanos, quando colocados em união, parecendo funcionar como lugar propício para a expressão dos sentimentos mais recalcados e vis e das mazelas mais mesquinhas dos envolvidos. Ou seja, seria o laço um lugar significativamente fértil para que “(...) tudo de mau da alma humana” (FREUD, 1921/2011, p. 15) pudesse se expressar, trazendo rememorações de uma espécie de estado de sono.

Por fim, segundo Assoun, em "Psicologia das massas", vemos claramente nas massas a tração dos ideais, desde o mito edípico. Aliás, dos ideais e suas ambivalências (LINDENMEYER, 2018, p. 432). Talvez possamos supor que o peso do segundo elemento também tenha, em certo momento, ajudado a produzir os questionamentos aos líderes, em contribuição para nossas atuais localizações. Talvez.

De qualquer forma, outro ponto para o qual Freud chama a atenção, é o da diversidade dos grupos. Haveria múltiplas formas de unir as pessoas. Grupos passageiros e instáveis, grupos mais circunscritos, populosos e, ainda, grupos mais duradouros, estruturais e estruturantes. Sobre estes últimos, diz, especialmente, que "As informações contraditórias se originam da consideração das massas ou associações estáveis, em que os seres humanos passam toda sua vida, e que 
tomam corpo nas instituições da sociedade" (1921/2011, p. 24). De qualquer modo, o fundamental, aqui, é que alguns elementos incomuns surgem em todos estes agenciamentos, ou seja, estes não ocorreriam apenas em situações de liquefação, temporalidade curta e/ou instabilidade, mas definiriam estruturas institucionais que não apenas marcariam momentos da história, como a atravessariam como fundamentos balizadores essenciais ao longo de seu tempo, definindo tanto percursos subjetivos quanto fundamentos objetivos.

Alguns destes elementos, inclusive, poderiam ser destacados: uma predisposição ao rebaixamento intelectual, a dinâmica da influência/sugestão não como resposta conclusiva, mas como fenômeno de base -, a ação da libido como carro chefe da cena (FREUD, 1921/2011, p. 32), ou, especialmente neste último ponto, em outras palavras, a famosa libido de Eros como fundamento de associação. Sobre este último elemento, Freud diz:

(...) não separamos disso o que partilha igualmente o nome de amor, de um lado o amor a si mesmo, de outro o amor aos pais e aos filhos, a amizade e o amor aos seres humanos em geral e também o dedicado a objetos concretos e ideias abstratas (FREUD, 1921/2011, p. 32).

Este amor que faz liga, que ainda que não deixe de resguardar sua função essencial, se apresenta também em outros e novos formatos, ainda que conserve, suficientemente, sua natureza original, seria um dos operadores de nossas dinâmicas associativas, seja em elementos macro ou micro de nossas vidas, públicos ou privados, íntimos ou no que há de mais coletivo em nós. Talvez, como elemento metamorfoseador, muito possivelmente, de nossas solidões em composições de laço. No entanto, na abordagem moderna, o amor se dá em relação ao pai, ao chefe, à lei e à ordem. Um amor que, como uma referência esquemática, centraliza nosso mundo e o define em categorias subsequentes e localizações a médio e longo prazo. Hoje, no entanto, este amor nos parece ainda mais irrequieto - e se sempre o fora -, com certeza, mais autorizado à volatilidade. Ele muda, transmuta e questiona. Descentraliza o objeto amado e, talvez, desta forma, pluraliza o próprio amor. Passando da era de um amor-divino à de um amor-parceiro. 
Em outras palavras, talvez seja Eros a nossa necessidade - e desejo - de realizar composições. Um componente ainda essencial para fazer uma liga que, ainda que não de forma solitária, faça, então, a composição de nosso tão buscado e almejado nó.

Sigamos.

\subsection{0 mal-estar na civilização: a dimensão complexa dos conflitos entre intenções particulares e construções coletivas}

Escrito às vésperas do colapso de 1929 da bolsa de Nova York, e dando continuidade a seu interesse pela dimensão complexa dos conflitos entre intenções particulares e construções coletivas, Sigmund Freud publica, em 1930, uma de suas maiores obras primas, de nome "O mal-estar na civilização" (19291930/1969).

$\mathrm{Na}$ experimentação de diversos títulos, como, por exemplo, “A infelicidade na civilização", Freud chega ao nome final de seu texto, que se debruça sobre o fundamental antagonismo entre as exigências dos instintos (pulsões) e as restrições civilizacionais. É nessa direção, que, em carta a Fliess, Freud diz: "O incesto [nosso marcador já citado] é anti social e a civilização consiste em uma progressiva renúncia a ele" (1929-1930/1969, p. 76). E remarca: “(...) podemos, com justiça, responsabilizar nossa civilização pela disseminação da neurastenia” (1929-1930/1969, p. 76). Tal marca, a de oposição entre as dimensões da pulsão e da renúncia, é recorte que se destaca, por exemplo, na aproximação de Bauman, em sua interpretação do texto freudiano, promovendo tal conflito como uma das possibilidades fundamentais para o sujeito (moderno).

Freud inicia seu texto abordando o tema do sentimento oceânico, uma espécie de sentimento religioso, "o sentimento de um vínculo indissolúvel, de ser uno com o mundo externo como um todo" (1929-1930/1969, p. 82). Aborda tal declaração por diversos pontos de vista. Em um deles, aponta para a possibilidade de nosso ego não possuir fronteiras tão permanentes, mas que é fruto de um processo de desenvolvimento que envolveria, a todo o tempo, ele e o meio - os outros, mais ou menos íntimos, ou mais ou menos distantes -, com os quais, de alguma forma e em algum grau, viria a se relacionar. Ou seja, as fronteiras não 
seriam fixas, rígidas internamente, e as dinâmicas e marcações do meio e do outro $^{4}$, na constituição do sujeito, seriam impressionantemente constantes.

Uma criança recém-nascida ainda não distingue seu ego do mundo externo como fonte das sensações que fluem sobre ela. Aprende gradativamente a fazê-lo, reagindo a diversos estímulos. Ela deve ficar fortemente impressionada pelo fato de certas fontes de excitação, que posteriormente identificará como sendo seus próprios órgãos corporais, poderem provê-la de sensações a qualquer momento, ao passo que, de tempos em tempos, outras fontes lhe fogem - entre as quais se destaca a mais desejada de todas, o seio da mãe (...). Desse modo, pela primeira vez, o ego é contrastado por um 'objeto', sob a forma de algo que existe 'exteriormente' e que só é forçado a surgir através de uma ação especial (FREUD, 1929-1930/1969, p. 84-85).

A tendência - e interdependência - dessa aproximação, envolvimento e conflito com o outro estaria presente em constância quase que total durante o processo de existência humana, como podemos observar pela seguinte passagem, sobre um dos movimentos mais primordiais de nossa estruturação:

Surge então uma tendência a isolar do ego tudo que pode tornar-se fonte de tal desprazer, a lança-lo para fora e a criar um puro ego em busca de prazer, que sofre o 'confronto' de um exterior estranho e ameaçador (FREUD, 19291930/1969, p. 85).

O texto de 1930 segue ao escrito “O futuro de uma ilusão” (1927/1969), que tratara, também, de um ponto fundamental em nossa cultura - e, inclusive, no que toca às nossas discussões contemporâneas -: o tema da religião e sua função e disfunção - social em relação às suas dimensões de regressão subjetiva e da importância na crença em um pai protetor, em um pai fundador (RODRIGUES, 2015, sem pág.). Uma referência que, entre Deus e pai, tudo sabe, protegendo, assim, o homem dos perigos que o afetam e o colocam diante do seu próprio e, ao menos a princípio, doloroso e insuportável desamparo.

\footnotetext{
${ }^{4}$ Em Lacan também veremos a importância do lugar do Outro. Outro da atmosfera do ser falante que, em articulação com suas três esferas - real, imaginário e simbólico - monta o sujeito. Este outro-referência, que é marcador de seus limites e possibilidades, vem, para Lacan, como A maiúsculo (de Autre), como lugar de seu código, "O A [que] encerra o tesouro da linguagem, que é preciso supor já presente, para que dele possam ser extraídos, sob o selo da intenção, os elementos que vêm inscrever-se, uns após outros, para se desenrolarem sob a forma de uma série (....) ou, dito de outra maneira, de uma frase que descreve um circuito até que algo seja realizado, fechado." (LACAN, 1968-69,/2008, p. 50), concebendo, assim, o sujeito. "Que quer ele? Que quer o Outro? É o que me pergunto?" (LACAN, 1968-69/2008, p. 52),
} 
O tema conflitante entre pulsões e civilização parece, com maior ou menor sutileza, estar presente desde tempos remotos nos textos de Freud. Contudo, um elemento é, sempre, seu núcleo fundamental: é a partir dos marcadores do inconsciente que o psicanalista sempre montará sua concepção de civilização e seus desdobramentos. A concepção do superego, por exemplo, formaliza bem tal composição teórica. É esta elaboração conceitual, desenvolvida por quatorze anos, que tem papel fundamental tanto na conceituação do psiquismo, quanto na direção do tratamento clínico, e nomeia de forma bastante significativa o lugar do outro e da cultura na constituição individual. O conceito de superego é considerado fruto, exatamente, do recalcamento de certas pulsões sexuais e da internalização de certas leis, já fundadas, em suas primeiras relações sociais, ou seja, o meio familiar. É o superego que ligará o sujeito ao mundo com um cenário também marcado por um conjunto de leis que lhe fora transmitido e, agora, lhe é estrutural. Regras que organizam e organizarão o encontro social do sujeito. "Dá-se o primeiro passo no sentido da introdução do princípio de realidade, que deve dominar o desenvolvimento futuro" (FREUD, 1929-1930/1969, p. 85), constituindo e fazendo a manutenção da perspectiva da civilização de forma vital.

Para dar suporte às renúncias (pulsionais) que se colocam em jogo, um membro forte deveria organizar esse clã civilizacional. A este, pertenceria o lugar, já sinalizado anteriormente, do líder, do pai, de Deus, do exército e das fortes instituições representativas.

Na contiguidade dessas renúncias, e desse corpo civilizacional que se estrutura, Freud diz que o homem se aproxima de uma espécie de "Deus de prótese" (1929-1930/1969, p. 111), subvertendo as regras pelo domínio e buscando instaurar o paraíso em Terra.

Mas digamos que esse desenvolvimento racionalista não saiu de modo tão perfeito e, como consequência dessa análise, chegamos também a um outro ponto fundamental:

(...) ficamos inclinados a assumir o ponto de vista (...) de que, na vida mental, nada do que uma vez se formou pode perecer - o de que tudo é, de alguma maneira, preservado, e que, em circunstancias apropriadas (...) pode ser trazido de novo a luz (FREUD, 1929-1930/1969, p. 87). 
A descoberta e a inauguração do conceito de inconsciente já realizam uma divisão de águas, fundamental, para a análise de qualquer fenômeno, também sociológico, a partir de então. É por essas e outras direções que vemos o que Freud pontuara, desde então: "É óbvio, portanto, que $O$ mal estar na civilização é uma obra cujo interesse ultrapassa bastante a sociologia" (FREUD, 19291930/1969, p. 85). Ultrapassa, mas, podemos dizer que a inclui.

A complexa engrenagem que parece nos (des)organizar parece, também, deixar claro que nossas fronteiras, sejam de produção de conhecimento, sejam de constituição do sujeito, em nossas desdobradas relações com o mundo externo e com nossos (in)cômodos internos são muito mais delicadas e sofisticadas do que a olhos nus parecemos supor. Aliás, ainda que não cheguemos a lhes adentrar profundamente, é importante apontar que tais instâncias teórico-práticas parecem funcionar muito mais em uma estrutura de rede do que como formulações fechadas. ${ }^{5}$

Por fim, encontramo-nos na polêmica lógica do na natureza nada se cria, nada se perde, tudo se transforma. Parece haver algo da organização do sujeito, aqui, que insiste, persiste e deve ser ouvido. O texto "O mal estar na civilização" (1929-1930/1969) nos indica, afinal, que há, ainda, algo da organização deste sujeito no espaço que, tanto o compõe, como, nele, o inaugura, sobre o qual ainda temos muito, enfim, sobre o que insistir e nos debruçarmos.

Neste ponto, ainda vemos as massas organizadas como identificação unária em função da maestria de um líder. A orquestra múltipla e interdependente que mantém seu ensaio e cria novas composições sem a presença de um maestro parece deslizar das narrativas de "O mal estar na civilização" (1929-1930/1969), apenas como força de esperança dos autores aqui presentes. Nosso questionamento acerca da segregação pelas diferenças vem, a partir daí, em um segundo tempo.

\footnotetext{
${ }^{5}$ A concepção de articulação em rede como uma espécie de desenho para a psicanálise foi delineada pela primeira vez pelo psicanalista Renato Mezan, apresentando o quão ampla e articulada se apresenta sua composição teórica (MEZAN, 1998, p. 296).
} 
Vejamos se, por aqui, poderemos continuar. A psicanálise é mesmo a "ciência dos rastros" (OLIVEIRA, 2008, p. 110) que permanece nos trazendo questões e ajudando na composição de invenções. 


\section{Novo piso: Alemán e Laclau}

\subsection{Dos fins dos sentidos, dos grandes relatos, dos Estados Nacionais: a crise da unidade}

Localizemos agora dois autores específicos que abordam a atmosfera dos laços sociais na chamada pós-modernidade e de como estes disputam o campo da política no contemporâneo. O psicanalista Jorge Alemán e o cientista político Ernesto Laclau foram escolhidos por alguns motivos. O principal deles é o fato de ambos se alimentarem de alguns conceitos e referências de leituras da psicanálise lacaniana para operar no campo da política na atualidade. Além disso, contribui o fato de ambos articularem perspectivas de execução, ou seja, que envolvem uma referência à prática da organização política hoje, a partir de suas reflexões teóricas.

Unindo tais conceitos e paradigmas, buscamos desenvolver e oferecer a proposta de uma leitura para tais fenômenos. Sigamos, então, para entender o ponto de vista destes autores, que agregam, ainda mais, ao enriquecimento de nossa escuta sobre a passagem do mundo moderno à sua pós, como trazida por Zygmunt Bauman em nosso primeiro capítulo. Que alguns outros e novos ângulos e pontos de vista possam, também, a partir de suas diferenças, somarem-se à constituição, ainda que passageira, de um solo comum que nos sugira caminhos.

É já em 1983 que o cientista político Ernesto Laclau publica o texto "Os novos movimentos sociais e a pluralidade do social", apontando, em linhas gerais, às dimensões e formas radicalmente novas assumidas pelos fenômenos sociais pós-modernos e seus conflitos, ao longo das últimas décadas. Ao expor-se à pergunta: "por que novos?", Laclau pontua que essas lutas denotavam a crise de um paradigma bastante específico dentro das ciências sociais, o da dimensão de unidade. Essas unidades se dirigiriam a todas as atmosferas: unidades de agentes $\mathrm{e}$ das variedades - e variações - de tipos de conflitos, formatos e espacialidades. Como unidades de agentes, Laclau exemplifica com as lutas camponesas, burguesas e proletárias, em uma suposta unidade entre as várias - ainda que bem restritas, comparadas com a diversidade das narrativas atuais - posições do sujeito. Como unidades de conflitos teríamos a produção específica e virtual de um objeto delimitado. Por fim, teríamos a definição do elemento espaço, este que 
se trataria, até então, na atmosfera moderna, como um espaço com características de estrutura política unificada $\mathrm{e}(\mathrm{m})$ uma representação de interesses também muito bem desenhados e, segundo o autor, significativamente claros.

Segundo Laclau, nos tempos modernos, tratar-se-ia, ainda, do significado de cada luta, e de uma luta localizada, percebida e transmitida mais como um processo histórico - em um processo de movimento subjacente da história, marcando tradições praticamente imanentes - do que um processo de conscientização. Este seria marcado, talvez, como prática de caraterísticas mais próximas das que podemos localizar mais na atualidade. Prática esta que nos leva a cadeias significantes, fluxos e associações mais fluidos, instantâneos, pautados em uma categoria de um "fazer com" - tais expressões encontraremos na bibliografia psicanalítica lacaniana que compõe passos mais adiante desta dissertação.

A dimensão de unidade, trazida por Laclau, também se dirige à perspectiva das referências únicas e centralizadoras, capazes de representar e ter algo a dizer sobre o sujeito. A identidade do soberano ainda é fundante neste período moderno. Busca-se que apenas as mesmas - e familiares referências - sejam contínuas, palatáveis, tenham força. "Ainda estamos em tempos da dimensão homogeneizadora do discurso único”, (ALEMÁN; PUJÓ, 2013, p. 154).

$\mathrm{Na}$ atmosfera narrativa da pós-modernidade, segundo Alemán e Pujó, teríamos, até aqui, a presença e a hegemonia “(...) do sujeito empreendedor (...), autoconsciente e dono de si” (ALEMÁN; PUJÓ, 2013, p. 156), um sujeito que, como o entendemos, parece significativamente encarnado e articulado com a dimensão da verdade.

Sob a ótica da própria insígnia de pós-modernidade, Alemán e Pujó pontuam:

Em todo caso o termo modernidade não me parece mais designar este mundo de maneira relevante. Na verdade este foi o sucesso do termo "pós-moderno" para mostrar que a modernidade não havia sido superada por uma nova etapa, que não havia sido deixada pra trás como outros momentos históricos, mas algo que a ultrapassava havia emergido entre suas dobras (...). A expressão hipermodernidade, que poderia ser usada, não me convence, porque parece dar a ideia de uma exaltação do moderno, quando a questão é muito mais complexa. (ALEMÁN; PUJÓ, 2013, p. 158). 
Não se trataria mais, segundo os autores, de uma espécie de continuidade, ou da exacerbação das características da modernidade para sua pós, mas de mudanças de paradigmas e deslocamentos fundamentais. Novos posicionamentos que estabelecem, de fato, novas estruturas, novos laços, novas políticas.

Dentre as quedas e as necessidades de reformulação da pós-modernidade, Alemán e Pujó apresentam "a proposição kantiana do uso público da razão" (2013, p. 159) e da própria ideia de revolução como possibilidade deliberativa positiva (2013, p. 159). Aliás, ambos destacam a queda da revolução, em sua perspectiva valorativa e simbólica, como uma das marcas mais importantes dos tempos contemporâneos. Ou seja, isso fala da queda de amarras ou, ainda, do que entendemos como a queda da centralidade de referências diminutas, hegemônicas e estáveis e a diminuição das pautas homogêneas (o que envolve a própria perspectiva de revolução), junto à queda da representatividade.

Apoiando tal ideia, uma filosofia política mais pautada nos processos de adaptação teria ajudado no processo de destituição do lugar de autonomia e subversão até então vinculados às narrativas que abordavam o tema da revolução (ALEMÁN e PUJÓ, 2013, p. 159). Ainda que, em seu diálogo, os autores não neguem a importância da reformulação de alguns destes termos. Na resolução de tais impasses, Alemán e Pujó pensam em algumas possibilidades, onde destacamos a seguinte como importante para eles, e para nós, pois colocam uma possível aproximação quanto ao que considerariam como uma "política de inspiração lacaniana":

O que chamamos de 'sociedade' não é uma totalidade plena e objetiva, é atravessada por impossibilidades que deslocam seu enredo, por elementos heterogêneos (...) e também, claro, por o que Laclau chama de antagonismos, que parecem constitutivamente impossíveis de serem reabsorvidos num movimento histórico com um significado finalístico. Nesse ponto, a política torna-se um "saber fazer lá" - como diria Lacan - com o real impossível. O que, como afirmamos com frequência, põe em questão a ideia clássica de revolução, como o projeto capaz de mudar toda a base da estrutura social em sua totalidade. Emancipação, por outro lado, é uma negociação tensa e permanente com o impossível (ALEMÁN e PUJÓ, 2013, p. 161-162).

A nosso ver, tais deslocamentos e colocações parecem nos colocar muito mais em um trânsito que nos leva a tempos de ocupações do que de revoluções; de 
deslizamentos do que de rompimentos. Ou, ainda, temos, ao menos, que repensar o próprio paradigma de revolução em relação ao modo como utilizado até aqui.

Em direções que conversam com a análise de Alemán e Pujó, o cientista político Ernesto Laclau aponta, igualmente, à destituição, hoje, de uma "visão do político como espaço fechado e homogêneo" (1983, sem pág.) como marca importante da passagem do mundo moderno à sua pós. O que passamos a entender, então, é que a antiga dualidade e matemática, aparentemente mais simples, que se dá na referência a oposições, como esquerda/direita, democratas/republicanos, burgueses/proletários, com o peso de suas respectivas referências simbólicas, muito bem costuradas, passam a se tornar menos consistentes, menos necessárias, mais abandonadas, menos, efetivamente, localizadoras de algo ou alguém.

O imaginário moderno político do vigor das instituições, da organização que se desdobra sempre a partir de um foco central e, ainda, o do poder de uma hierarquia representada e encarnada também a partir de uma referência fundamental - a exemplo da figura de um líder, de um pai ou de um governo -, parece dar, aqui, início a um importante declínio - ainda que não, a nosso ver, sem contra-forças importantes, como a conhecida empreitada religiosa, especialmente protestante, atualmente presente com nova força no Ocidente.

Afinal, não é sem a referência típica que se desdobra em processo de transição, ainda que sem a institucionalização (ainda que seja disso também que se trata) de algo tão claro como a fisionomia anterior, e dos inevitáveis perigos de retornos violentos, inesperados - e desesperados - de apego e marcação de uma identidade (política) que começa a ruir, que se processam os deslocamentos e transformações da história.

Como diz Bauman, estamos em tempos de interregno (2016). Caminhos complexos, conflituosos e reais de uma travessia fundamental do mundo moderno à sua pós. 


\subsection{Atualidade: o pessoal é político}

É em um sem número de possiblidades que nos encontramos no cenário pós-moderno. Resta-nos saber quais amarrações são possíveis diante delas, e como poderemos fazê-las.

Alemán e Pujó nos localizam diante de tal questão. Em suas próprias palavras, seus apontamentos se apresentariam a partir do seguinte lugar:

A urgência de um espaço discursivo marcado por Freud, Lacan, Marx e Heidegger, junto às questões de inconsciente, mais valia e objeto a (...). A necessidade de uma atmosfera antifundamentalista e antitranscendentalista (...) e o fim da filosofia (...). No lugar disso, o interesse pela construção histórica da subjetividade, o sem sentido e o fim dos grandes relatos (ALEMAN, PUJÓ 2013, p. 152).

O movimento espanhol 15-M é citado por Alemán como um excelente representante da (re)organização moderna do que poderíamos chamar de laços sociais fruto de uma nova arquitetura na organização política. Durante esse movimento, protestos ocorreram em diversos pontos da Espanha, durante o ano de 2001, com o registro de partirem espontaneamente da sociedade civil e com o apoio de algumas organizações, mas sem nenhuma institucionalização central. Reivindicavam mudanças heterogêneas e apresentavam a crítica à representação partidária (ESTRELLA, 2017). Não se distanciam disso as ocupações de Wall Street e as passeatas de junho de 2013 no Brasil.

Em todos esses episódios, parecia ser narrado algo que não ocupava mais a cena dos ideais coletivos. O possível era ordinário. Não havia mais a impostora revolução. As demandas balbuciadas traziam marcas do cotidiano: era por 20 centavos, era pela vida das mulheres, pelo fim do genocídio negro. Dentre os gritos, apresentava-se a impotência de um pai fálico. Mais valia o lugar - diverso e plural - de fala: civis, mulheres e homens - comuns - nos representavam. Subverter as formas de gozo, até então definidas, no entanto, acompanha novas marcas e marcações. Novos significantes ocupavam a cena social. 
Para Laclau, chegaríamos, hoje, ao impossível de uma política tal como traçada em seus moldes anteriores, ou, em outras palavras, de uma política que se produza sem articulação e hegemonia ${ }^{6}$ (1983, sem pág.).

A partir de todo esse cenário narrado, como, hoje, então, nos encontraríamos? A partir de quais pontos, quais enlaces, quais marcações?

Parece que nos aproximamos cada vez mais, na atualidade, da lógica de uma política mais fragmentária, mais instantânea, mais pontual. Resta-nos saber se é possível fazer com que isso seja positivado e produza elementos de conexão e teias importantes, em termos civilizacionais, satisfações pulsionais e possibilidades coletivas.

Segundo Laclau, o que prevalece, hoje, distintamente dos tempos modernos, seria a autonomia e a indeterminação, tanto das posições quanto dos tipos de relações. Em outras palavras, as identidades fixadas da era moderna passam a cair como forma de entendimento do que podemos chamar hoje de uma “identidade global" (LACLAU, 1983, sem pág.). Até mesmo o termo "luta de classes" passa a se tornar bastante insuficiente para descrever os atuais conflitos sociais (LACLAU, 1983, sem pág.). Laclau chamará isso de uma "crise, na teoria diacrônica dos estágios" (1983, sem pág.). No que podemos entender que hoje, uma determinada posição do sujeito não forneceria mais, automaticamente - ou naturalmente (como podem também alegar alguns) -, nenhuma determinação necessária em relação às demais, tornando-se, deste modo, impossível relacionar uma série subsequente, racional, de estágios (LACLAU, 1983, sem pág.). Restanos saber se: 1) é disso - da perspectiva de uma lógica racional - que, ainda, realmente, se trata; 2) Se há outros, a partir de outras localizações e lógicas, modos de fazê-lo.

É nessa direção que pensamos que, considerando a relação dialógica que cada fenômeno social tem com seu entorno, se as identificações e, logo, as identidades sociais, não estão mais tão definidas, por contiguidade, o lugar da

\footnotetext{
${ }^{6}$ A concepção de hegemonia é desenvolvida por Laclau e Mouffe, com base nos desenvolvimentos conceituais de Gramsci sobre suas ideias pós-marxistas de agenciamentos sociais a partir das novas referências contemporâneas. Conceito defensor de uma prática, para além da aliança de classes, do abandono, por parte dos diversos grupos sociais, de uma (auto) referência corporativista. Por uma conexão a partir das diferenças, na pauta de uma ideologia aberta e agregadora: “(...) cimento orgânico unificador de [novo] bloco histórico” (ALVES, 2010, p. 85).
} 
representação se tornará cada vez mais problemático. É nessa direção que Laclau considera que o político passará a deixar cada vez mais de ser um nível social: definido hierarquicamente, capacitado de seu poder representativo, institucionalizado e intitucionalizante, para ser uma dimensão presente, em maior ou menor escala, ao longo de toda a prática social (LACLAU, 1983, sem pág.). Para este autor, "O político passa [a bem da verdade], a ser uma das formas possíveis de existência social" (1983, sem pág.). O processo faz jus ao título do texto: é de novos movimentos sociais que se trata. E estes tratam de uma crescente politização da vida social.

O slogan feminista, "o pessoal é político", dentro dessa atual perspectiva, nunca foi tão significativo e representativo. Segundo Laclau, mais do que nunca, veríamos ruir tanto a função quanto a estrutura política como espaço fechado e homogêneo. "O fator pessoal, é fator político" (LACLAU, 1983, sem pág.), ainda que isso não ocorra, como já dito, sem possíveis tentativas - aliás, talvez ainda bem ferozes - de frear a história e a política, nessa nova direção.

Para Laclau, a noção democrática seria vista, nesse fim de século, como algo a se desconfiar tanto pela esquerda revolucionária quanto pela direita fascista (ainda que o possam ter sido também assim em outros momentos). Nos anos 1980, a questão se acaloraria mais com a queda das estruturas comunistas e os questionamentos acirrados em torno da questão liberal. Na América Latina, no entanto, com uma elite frágil sempre apta ao estatuto de golpes militares, a esquerda acabaria por se unir ao discurso de redemocratização (LACLAU, 1999). Não, talvez, sem pagar, no entanto, um alto preço por isso. Para Laclau, ainda que partindo de uma crítica à uma democracia liberal representativa, há a importância de se pautar formas alternativas de organização política, em que a representação (seja como mero deslocamento ou destituição radical), o papel do Estado e da sociedade civil, ocupam lugar central (LACLAU, 1999). Para o cientista político, democracia participativa, radical e de presença são algumas das designações dos novos modelos e propostas a serem articulados (LACLAU, 1999). De qualquer forma, como laço, a centralidade do poder parece começar a ruir.

Já Alemán e Pujó pontuam que a ênfase expressa pelo espírito pósmoderno dá destaque à problemática da contingência, da anti-essência, do 
interesse pelas condições históricas da subjetividade, do "nonsense" e do fim das grandes histórias (2013, p. 152). Como questões fundamentais e consequentes, destacam o risco da perigosa aproximação entre a derrocada das grandes histórias e o abandono da perspectiva da ideologia, da própria política como tema catalizador da humanidade em sua organização social e de uma recusa por permanecer se pensando a questão emancipatória. Os autores discorrem, ainda, sobre o perigo da valorização e elogio do cinismo, do ceticismo e da fascinação pela globalização e pela sociedade da informação, do não estabelecimento do compromisso de qualquer causa e da possibilidade cada vez maior de se "brincar" - palavra do próprio autor - de se tornar “(...) um expectador lúcido de eventos” (ALEMÁN; PUJÓ, p. 153).

Sobre a democracia, o psicanalista Jacques-Alain Miller diz: "A democracia, com efeito, não é apenas o poder da maioria, mas a proteção das minorias" (MILLER apud FIGUEIROA, 2018, sem pág.). Essa política que opera o laço social dependerá, portanto, da configuração do sistema na qual está a operar. E, quanto a isso, Alemán e Pujó são claros: “a diferença absoluta existe [apenas] na igualdade" (2013, sem pág.). Haveria de se ter essa irredutível base para se poder operar as diferenças.

Como questão de sobra, resta-nos pensar, então, junto com estes autores, que, se as referências centrais, desdobradoras de determinadas estruturas de laços, estão a ruir, quais são as (outras) construções possíveis, para além de um caos, ao mesmo tempo, desconcertante e indiferente - ou desconcertantemente indiferente -, como atualização dos tempos pós-modernos? Junto à realidade descrita e à força dessas novas narrativas, quais conceitos poderiam, então, nos ajudar a catalisar tais processos de modo de vida, com certa objetividade e funcionalidade, a fim de não ficarmos em um perigoso deserto habitado, tendo como exclusiva e possível conduta a negativação do momento atual?

Sobre essa questão, Laclau e Mouffe, ainda bem, nos trazem sugestões:

(...) romper com o essencialismo ortodoxo a partir da crítica de todo tipo de fixação e do caráter aberto e incompleto de toda identidade. (....) proporciona $[\mathrm{r}] \mathrm{o}$ arcabouço teórico para pensar a identidade como relacional (LACLAU; MOUFFE, 1987, sem pág.). 
Marcus André Vieira também propõe uma via de desdobramento da questão que vimos construindo: “É preciso, então, entre outras ações vitais, em defesa da legalidade democrática tão ameaçada em nossos dias, também encontrar e saber falar com esses "sujeitos divididos"” (2018a, sem pág.). Abandonar, portanto, o ideal de unicidade e de um ser acabado da ciência, que faz registro nos moldes da ciência moderna, para se ocupar do registro do sujeito forjado pela narrativa da psicanálise, especialmente, pela psicanálise lacaniana: sujeito inacabado, sujeito itinerante, sujeito à borda de uma crença - e de uma possibilidade - de lugar da verdade; sujeito falta-a-ser.

Por fim, no cenário pós-moderno, as ruas e as redes parecem ocupar os lugares dos planaltos e das instituições, até então fixadas e nomeadoras. As demandas, finalmente, são vistas como heterogêneas, diversas, plurais e radicalmente conflitantes, não se limitando às suas oposições. O cotidiano se tornou o espaço para o possivel impossivel, e as lutas parecem estar mais encarnadas em lugares de fala, em corpos como plataforma e em me representa! civis e ordinários...

Vejamos, agora, a que bricolagens tais apostas poderão nos levar.

\subsection{Solidão comum, significante vazio e ato instituinte: de que forma e onde se produzem os novos atos?}

pedra de pedra de pedra o que a faz tão concreta se não a falta de regra de sua forma assimétrica incapaz de linha reta?.

Arnaldo Antunes, Pedra de pedra

A questão que nos (des)norteia até aqui é: mas há, então, de ser possível fazer algo com a atual configuração pós-moderna? Essa que se expressa, a nossos olhos, tão precária, tão contingente, tão diversa, tão inacabada, tão, consumivelmente insatisfeita? 
Próximo ao grupo de discussões contemporâneas, composto por atores como Chantal Mouffe, Ernesto Laclau e Slavoj Zizek, o psicanalista argentino Jorge Alemán apresenta, dentre outras, a experiencia do inconsciente como proposta para se pensar, de forma crítica, a democracia na atualidade (ESTRELLA, 2017). Sobre a pós-modernidade e a importância de tal aproximação, Alemán diz: “Ali onde o indivíduo neoliberal do gozo autista é, o sujeito excêntrico do inconsciente deve advir" (2010, p. 20). Tal aproximação, segundo Alemán, distinguiria a suposta relação amalgamada entre a política e a atmosfera das identificações (2010, p. 44) - engodo da fantasia, alimentado e suturado pelo real do capital.

A nosso ver, a experiência do inconsciente se embasa, ainda, em perspectivas como o meio dizer e o não todo, experiências que, acreditamos, nos ajudam a pensar o fenômeno da política também como não toda ou "impolitica" (MACÊDO, 2014, sem pág.). Acreditamos que a proposta de Alemán pode nos ajudar a experimentar isso, em uma dinâmica de corte e confronto a um suposto discurso de completude e unicidade racional, realizando um questionamento realmente direto aos ideais modernos, de positivismo, apelo à consciência e controle e domínio do homem. Os sólidos - a ruir - bauminianos (BAUMAN, 2001, sem pág.).

A concepção de inconsciente de Alemán é interessante, aliás, para o enriquecimento de nossa leitura, já que, a partir daqui, não se trata mais mesmo apenas de controle, domínio e razão: "Vivemos em tempos de desregulamentação, de descentralização (...) em que se assiste (...) ao surgimento da política da vida", diz Bauman em entrevista (PALLARES-BURKE, 2003, p. 308) - perspectiva que afeta, diretamente, a conformação de nossos atuais laços sociais.

Alemán e Pujó nomeiam Jacques Lacan como um pós-fundamentalista (2013, p. 152). Nessa direção, os autores atribuem e realizam o deslocamento de diversos valores. Alguns deles se dão por certo namoro da obra lacaniana e do trabalho de alguns filósofos como Ernesto Laclau, Antonio Negri e Alain Badiou. Aproximação que tem como intenção a indicação de, como Jorge Alemán diz, “(...) novas possibilidades no saber-fazer do laço social” (ESTRELLA, 2017, sem 
pag.). Dentro de tal perspectiva, Alemán e Pujó nos trazem alguns posicionamentos importantes, como:

(...) uma das vertentes pós-modernas da psicanálise [é]: o sujeito dividido, constituído no campo do Outro e atravessado pela castração (...) ambas as perspectivas subvertem a representação do sujeito empreendedor da modernidade, autoconsciente e dono de si (ALEMÁN E PUJÓ, 2013, p. 156).

Fazendo um atravessamento do ser uno da modernidade para o ser plural de sua pós, vemos que a psicanálise, desde Freud, parece já nascer com os pés no vanguardismo, cumprindo tal amarração com a dimensão que lhe é ofertada, em seguida, pelos desenvolvimentos lacanianos, como núcleo posterior a ser desenvolvido. Alemán apresenta uma crítica e um caminho que a psicanálise traz para pensarmos esse sujeito empreendedor e pós-moderno. Nessa direção, o autor pontua a importância da perspectiva do sujeito do inconsciente para se pensar a democracia, já que, para ele "esta pressuporia não haver um significante que represente a todos" (ESTRELLA, 2017, sem pág.). Mas que, em direção contrária a isso, "trata-se exatamente do hiato entre representante e representação" (ESTRELLA, 2017, sem pág), já que “a construção democrática se dá[ria] a partir do impossível de se representar, a partir de um lugar vazio e da noção de que haverá sempre algo do sujeito que escapa à representação" (ESTRELLA, 2017, sem pág). A famosa tese lacaniana de que "O inconsciente é a política” (LACAN, 1966-67, p. 350), poderia ser lida, aqui, a partir da compreensão de que o inconsciente é um processo social, discurso do Outro e não fundamento autista, alocado nas profundezas do sujeito, como pudemos ver em algumas narrativas sobre a psicanálise, ao longo do percurso da história.

Em um campo onde a queda das grandes referências fundamentais parece estar sendo vista de forma especialmente negativada, a ferramenta do inconsciente parece ser um de nossos bons pontos de partida, dentre as ofertadas pela psicanálise lacaniana. De qualquer forma, entendemos que esta é a ferramenta de base utilizada tanto por Laclau quanto por Alemán. Essa é a referência que orquestra todos os demais elementos que compõem o sujeito lacaniano e lhes (e nos) serve de ponto de partida para se pensar o desenho dos laços, hoje, e(m) seu respectivo nó público: o campo da política. 
O discurso capitalista, que entendemos como sem espaço para a existência do sujeito lacaniano - inventivo, não-todo -, parece demandar, então, na contramão de seus excessos e nos registros de suas sobras, que subversões sejam possíveis. E é nessa direção que Alemán segue elencando aposta como um elemento fundamental em nossas intenções e práticas de transformação (o que nos parece muito próximo, ao menos nesse sentido, do que fazemos no espaço clínico, de trabalho), dada, inclusive, a importância destacada de não se posicionar em soluções vinculadas a certezas finalísticas e causais. Alemán diz:

(...) por sua vez, a exigência ético-política de tentar pensar em novas lógicas emancipatórias nos impõe pensar isso como um feito contingente e histórico, e não como a última palavra sobre a condição humana. Como você pode perfeitamente imaginar, isto inaugura problemas muito complexos sobre como uma experiência de transformação coletiva se vincula com aquilo que há de mais singular de cada um. (ESTRELLA, 2017, sem pág.).

Alemán considera que boa parte do fracasso de qualquer projeto político, até então, mesmo nos mais bem-intencionados, fundamenta-se por excluir de seu repertório a dimensão do sujeito freudiano (e, posteriormente, lacaniano). Dito de outro modo, pela não compreensão de nos entendermos como divididos, parciais, inacabados, inconstantes, fugazes e por assim buscarmos, igualmente produzir uma política em mesma direção, uma política total.

É com base em sua leitura do sujeito lacaniano e apoiado sobre a investigação da possibilidade de nascerem coletivos via a perspectiva das singularidades que Alemán se debruçará sobre a constituição de dois conceitos fundamentais para se pensar o campo da política atual. Esses dois conceitos são a composição de solidão comum e de atos instituintes. Ambos se constituindo como práticas que, por consequência, subverteriam o dispositivo capitalista, com sua narrativa de sujeitos e instituições totais.

São essas novas articulações que surgem, segundo Alemán, como a composição dos novos laços sociais: o encontro e a produção pela via da diferença - deslocamento substancial da época moderna, a referência ao sujeito lacaniano como base do campo de possibilidades e limitações. O sintagma solidão comum 
sintetizaria o horizonte alemaniano, na proposição da possível dinâmica de um coletivo de singularidades.

O termo "solidão comum" fora utilizado, originalmente, pelo filósofo Gilles Deleuze, designando a concepção de vida como uma potência livre que poderia subverter, com a quebra de alguns paradigmas - e a invenção de outros -, o dispositivo capitalista (ESTRELLA, 2017). Para Alemán, no entanto, o termo não significaria, necessariamente, a produção contínua, constante e fluida de certo conceito específico de subjetividade, mas a direção de se pensar o sujeito como um ser de linguagem, em uma operação que, inevitavelmente, implica um vazio estrutural. Nesse segundo modelo, ainda segundo o autor:

(...) o ato de criar, pode trilhar um percurso do desejo ao objeto, contornando este vazio irrepresentável ou uma singularidade que não faz norma, mas se torna, então, transmissível. Assim, o vazio, o hiato ontológico, deve ser considerado em todas suas consequências, não havendo potência ou produção de vida, que não sejam interrompidas [e logo, até mesmo por contingência, iniciadas] por esta falta do ser (...) o comum na experiência humana (ESTRELLA, 2017, sem pág.).

Teríamos, aqui, então, dois fundamentos essenciais: um hiato, um furo que codifica a descontinuidade do sujeito que, fundamentalmente, opera na função de encontro/desencontro e, nisso, a produção e a perspectiva de concepção do comum, utilizada pelo autor como uma possibilidade de espécie de borda. Talvez espécie de bordado inventivo - criação humana, que torne este vazio suportável. Trata-se da demanda pela morte da centralidade, da expectativa de complementaridade, da totalidade. É de outro encontro que se trata, é de outra política que se trata, é de outra concepção de laço; é da espécie de um nó.

O sintagma "solidão comum" (ALEMÁN, 2013) trata, então, de fazer "aparecer um sujeito" (ALEMÁN, 2013). Um sujeito a ser inventado; um sujeito que não está garantido por nenhum suposto saber que diga: "a este sujeito corresponde a revolução" (ALEMÁN, 2013).

Solidão comum surge como uma lógica emancipatória. O que Alemán, com suas próprias palavras, tenta fazer com, "ao contrário de manter todas as más 
notícias que tem a psicanalise com respeito à ideia de um projeto coletivo, vincular com algum tipo de experiência comum" (ALEMÁN, 2013) ${ }^{7}$.

É o que Alemán busca realizar, não pelo amálgama das identificações, mas pelo respiro do efeito das diferenças.

Diversos projetos e grupos sociais já compreendem a abertura de trabalho que as solidões engendram - aliás, nossos consultórios também. No entanto, o costume é de que os primeiros o façam por um sistema de referência à igualdade $\mathrm{e}$ à moral (unidade, dirigida/e demandada, do sujeito). A oferta da psicanálise pode se apresentar, no entanto, em outra direção: a partir do insistente da solidão, no encontro pelas diferenças, no respeito ao diverso, na produção de um comum que se faz com o incomum, ou seja, com o registro da alteridade onde, na radicalidade, “não há Outro do Outro" (LACAN, 1958-1959/2016, p. 315). É o encontro das singularidades (ESTRELLA, 2017).

Ressoa com isso o posicionamento de Alemán com relação à importância da entrada da perspectiva do sujeito lacaniano na narrativa e dinâmica de nosso nó político: "Está na hora de pensar a emancipação aceitando esta brecha na condição humana" (ALEMÁN, 2013) ${ }^{8}$.

A psicanalista Hebe Tizio também pontua, aqui, em direção aproximada: "O laço social é uma forma de fazer laço com o outro que conecta, e ao mesmo tempo separa, pois se sustenta sobre um vazio que abrigará a causa do sujeito, sua singularidade" (2006, sem pág.). E complementa: "Isso sinaliza que não há determinismo social, pois a causa está no sujeito" (TIZIO, 2006, sem pág.).

Seguindo essa direção propositiva da abertura para o sujeito da psicanálise lacaniana, como base e estrutura para se pensar o fenômeno social, os cientistas políticos Ernesto Laclau e Chantal Mouffe nos trazem o deslocamento de uma outra referência central no campo pós-moderno: a perspectiva de revolução (ALVES, 2010, p. 87). Nesse deslizamento, que se encontra na mesma retórica da queda dos grandes relatos, Laclau e Mouffe trazem à cena o fundamento da democracia radical, com características ancoradas nas perspectivas pósestruturalistas e na teoria lacaniana e nas referências pós-marxistas, adequando-se

\footnotetext{
${ }^{7}$ Transcrição do trecho compreendido entre o minuto 37:34 e 37:57 do vídeo citado.

${ }^{8}$ Transcrição do trecho compreendido entre o minuto 39:21 e 39:24 do vídeo citado.
} 
às novas pontuações pós-modernas (ALVES, 2010, p. 87). Não são, logo, pelas perspectivas de revolução e ruptura - ou de revolução como ruptura - que Laclau e Mouffe articulam o momento atual.

O conceito de "povo", de Ernesto Laclau, continua essa cena, oferecendo, então, uma ideia de como o cientista político pôde elencar a dimensão da política na atualidade. Esse conceito é compreendido como "um ato de instituição que cria um novo ator a partir de uma pluralidade de elementos heterogêneos" (LACLAU, 2005, p. 10). Conta-se, aqui, com "menos lógicas subjacentes e mais ações" (LACLAU, 2005, p. 15). E, nessas, há a "equivalência entre uma multiplicidade de demandas heterogêneas" (LACLAU, 2005, p. 17). Em outras palavras, a marcação fundamental das diferenças.

É também através de caminho aproximado que Laclau cunha o conceito de "significante vazio". Uma intenção nova para refletir sobre originais possibilidades de laços e, entendido por nós, como um vazio operador que, justamente, porque sem identidade prévia, história particular, coletiva ou endereçamento preciso, pode fazer caber diferenças e articulações que, em outras circunstâncias - ou em outros paradigmas, o que inclui determinados momentos históricos -, seriam impossíveis de se evidenciar e se inscrever.

No campo inverso de possibilidades de cola e descola, mas no de articulação, criação, experimentação e mesmo surpresa - como em um bom processo de análise -, a aposta seria, então, no encontro pelas diferenças, na transmissão de uma unidade heterogênea suportada pelo único meio que isso seria possível: o bordejar amplo de um significante (vazio).

A importância dos significantes vazios está em, justamente, homogeneizar um espaço social extremamente heterogêneo, considerando a articulação de demandas insatisfeitas que, antes do processo articulatório, não tinham nenhuma articulação entre si (MENDONÇA; VIEIRA JUNIOR, 2014, p. 127-128).

Para Laclau, "em sua expressão mais extrema, este processo chega a um ponto, em que a função homogeneizante é levada a efeito por um nome próprio: o nome do líder" (2005, p. 40). Nós, no entanto, a partir da dimensão do deslocamento das grandes referências, o chamaremos de ato instituinte. 
Nessa direção, Mendonça e Vieira Junior continuam:

É nesse sentido que para Laclau, democracia não tem necessariamente relação com instituições, com espaços políticos cristalizados como um parlamentos (...). Democracia é, antes, a construção de subjetividades populares, as quais podem ou não estar afinadas com os marcos institucionais (MENDONÇA; VIEIRA JUNIOR, 2014, p. 128).

Laclau complementa: "Sem a produção de variedade, não há povo, não há populismo, mas tampouco há democracia” (2005, p. 213).

Este lugar vazio do significante dimensiona que:

(...) elementos que fazem com que a dimensão da universalidade seja impossível de ser preenchida completamente. Neste sentido este lugar é sempre ocupado e reocupado, de forma precária por alguma particularidade (MENDONÇA, 2012, p. 132).

As costuras discursivas de Alemán e Laclau parecem abraçar bem aquele sujeito furado e inacabado. E, sobre isso, Lacan nos alerta: "Não se trata de produzir aqui a desordem do mundo, se trata de ler, ali, o não-todo" (19731974/2018, p. 210).

Os laços discursivos da pós-modernidade, subvertendo as narrativas de caos, fim do mundo e pura liquefação, parecem poder, como vemos através da articulação da linguagem e das escolhas conceituais de Alemán e Laclau, encontrar respaldo e elementos de reflexão em nosso campo teórico.

Para finalizar, chegamos, então, aos nossos atos instituintes - estes que podem ser entendidos, aqui, como o adensamento de um encontro circunstancial dos elementos, das diferenças tão curiosamente marcadas e, ao mesmo tempo, tão passageiras, instantâneas, evanescentes. Sobre tal conceituação, Alemán pontua: “O antagonismo lógico é constitutivo de toda sociedade: há um sujeito porque há

\footnotetext{
${ }^{9} \mathrm{O}$ não-todo lacaniano abraçaria, segundo Santiago, do que se trata a política na psicanálise: "a política que se deduz da alteridade própria do feminino" (2015, sem pág.), encarnada por uma escrita lógica. É quando é possível se deslocar da aproximação do discurso do mestre e de seu universal. "A política do não-todo toma os objetos como singulares, pois mostram-se refratários a toda exemplificação e predicação do que quer que seja” (SANTIAGO, 2015, sem pág.).
} 
uma fratura, existe uma sociedade porque primeiro há uma lacuna instituinte" (2010, p. 27).

$\mathrm{Na}$ marca desses atos e em seu caráter de subversão e protagonismo, Alemán os define como "a articulação de singularidades que povoam as ruas cidades fazendo rupturas na história (...) que podem insurgir como laço social" (ESTRELLA, 2017, sem pág.). Esses (novos) laços, realizados com base nas singularidades, já parecem marcar o impossível da relação (sexual), agora, também, no campo da política. No menor, no campo do laço, com um mais-um sempre presente, marca da diferença, e que parece nos ofertar mesmo a dissimetria do real. De qualquer forma, seja no laço menor, seja no laço mais amplo da política, parece ser essa mesmo a única forma de produzirmos alguma amarração para o que então nos resta de possível.

Escapando das referências freudianas - ainda que não sem elas -, segundo Alemán e Laclau, parece não ser mais mesmo das massas que se trata, mas de outra proposição, onde há um possível a se fazer com o que há de mais singular em nós.

É após, então, o encontro das solidões, de Alemán, o possível suporte de encontros do significante vazio, tensionado por Laclau e Moufe, e o vigor fluido do ato instituinte, apresentado, novamente, pelo primeiro, que haveria alguma costura possível para pensarmos em novas tessituras para tenros laços sociais e nossas atuais dimensões políticas.

\subsection{A chegada de uma era totalmente política, auto referida: a não necessidade de entidades prévias como constituição de solo comum e um comum que se dá em ato}

Eu tenho pensado muito na minha música como um pense-dance, como um feitiço, como um manifesto, como denúncia, como ponte.

Linn da Quebrada, Minha música é feitiço, manifesto, denúncia e também ponte 
É a partir de todas as localizações descritas até aqui que Laclau, por fim, diz não apenas não crer em um atual fim da política, mas que, muito ao contrário, acredita na chegada de uma lógica e espacialidade "totalmente política" (2005, p. 276). Com isso, entendemos que Laclau codifica a entrada de uma política que se faz no ordinário. De uma política que se faz no cotidiano. De uma política que está no lugar comum - e singular - dos lugares de fala. Que busca se apresentar pela marca da diferença. De uma política que se faz a partir das pautas - como nunca - do feminismo e do racismo -, dos grupos, até então, considerados minoritários. Enfim, de uma política que se faz com...

A noção de posições de sujeito no interior de uma estrutura discursiva se contrapõe diretamente ao privilégio das classes sociais e à garantia de sua unidade devido aos interesses comuns determinados pela posição nas relações de produção. Nesse sentido, toda posição de sujeito é uma posição discursiva, que participa do caráter aberto do discurso e que não fixa totalmente essas posições em um sistema fechado de diferenças (LACLAU; MOUFFE, 2004, p. 156).

Para isso, no entanto, Laclau aponta a necessidade de nos apropriarmos de outras possibilidades de leitura e interpretação para o plano histórico; de outras localidades do sujeito. Só assim, poderíamos, então, desterritorializar o campo da política. Deixando-a mais ordinária para torná-la, assim, também mais humana. Aliás, o cientista político encontra, para isso, na psicanálise, uma ótima parceira. (A)bordando a política atual a partir de sua leitura, sugere o (re)fundamento de vários paradigmas da ciência política enquanto veículo de interpretação para o real. A pós-modernidade, com toda sua dissolução - ou, como alguns preferem nomear, com todos seus deslocamentos -, parece ser uma ótima espacialidade para esse encontro. Como Laclau diz, aposta-se, agora, na “(...) dissolução das marcas de certeza [que] retira do jogo político todo tipo de terreno apriorístico no qual possa assentar-se, mas, por isso mesmo, cria a possibilidade política de redefinir constantemente este terreno" (2005, p. 276).

A partir da compreensão de Laclau, que poderíamos chamar de uma espécie de dinâmicas identitárias em processo, entendemos que, para o autor, tudo está em constante movimento e lhe é contingente. Encontramos isso, por exemplo, em Alves que, em seu estudo sobre Laclau e Mouffe, aponta que o social teria, para ambos, caráter sempre aberto e incompleto, e que “(...) nenhuma 
lógica hegemônica consegue[ria] dar conta da totalidade do social" (2010, p. 88). $\mathrm{Na}$ psicanálise lacaniana, conheceríamos, talvez, isso, como nenhuma lógica hegemônica consegue[ria] dar conta da totalidade do real - ou do sujeito.

Há o impossível de se dizer e o impossível de se governar. Sutilezas que sabemos mudarem completamente a concepção do sujeito moderno (desde Freud) e pós-moderno, posteriormente, com Jacques Lacan. Sutileza que, espera-se, talvez também faça diferença significava ao adentrar o discurso, e, logo, campo da política.

Ainda é nessa direção que Laclau e Mouffe trazem à cena a concepção de indecibilidade, onde: "Sem indecibilidade e contingência não é possível pensar as articulações hegemônicas contingentes e a política como atividade autônoma" (2013, p. 88). Assim também seriam as identidades e lugares políticos. E é nestas - e a partir destas - que a composição dos laços sociais de hoje nos levaria, cada vez mais, à narrativa ordinária da política. A narrativa de uma política que só se faz com marcas próprias e cotidianas. Sem definições antecipadas. Se o tempo largo das grandes mediações representativas está em dissolução, muda, também, sua plataforma.

As mobilizações populares que não mais se baseiam num modelo de sociedade total ou na cristalização, em termos de equivalência, de um único conflito que divida a totalidade do social em dois campos, mas numa pluralidade de exigências concretas, conduzindo à uma proliferação de espaços políticos (LACLAU, 1983, sem pág.).

Por fim, chegamos a uma questão fundamental de Laclau: “(...) será que a radicalização das várias lutas baseadas em uma pluralidade e de posições de sujeitos leva à uma proliferação de espaços, reduzindo a distancia entre representante e representado?” (1983, sem pág.).

É da possibilidade de um tecer democrático, a partir da narrativa do encontro das diferenças - e das singularidades -, tal como aparece igualmente em Alemán, que se trata aqui. A possibilidade de se estabelecer algum nó, ainda que contingencial, que dê conta - ainda que com alguma itinerância -, do campo coletivo. 
Laclau nos dá, especialmente, este terreno, com seu significante vazio. Alemán nos dá seu conteúdo, através de nossas solidões comuns. Finalizando a cena com sua possibilidade final, talvez não coincidentemente, o nosso ato (instituinte).

É nessa direção que, na historicidade versus a ontologia dos fenômenos sociais, a política de Laclau e Mouffe nos ajuda na constituição de uma leitura que acalma a lógica de paradigmas políticos essencialistas (LACLAU e MOUFFE, 2004, p. 22-23). Ainda, com isso, colaboram para que outros processos possam passar a serem pensados a partir de lógicas, como a já citada, da contingencialidade, apostando, assim, que nos distanciemos de uma leitura onde um movimento subjacente da história estruturaria e organizaria a marcação de nossos laços coletivos e, até certo ponto, já que estamos nomeando este processo aqui de História, públicos.

A proposta política de Laclau, Mouffe e Alemán também parece, em outras palavras, buscar cada vez mais se deslocar de suas referências ao chamado grande Outro, da psicanálise lacaniana (referência também, como já dito, destes autores), para se apresentar nos laços itinerantes, mas também intermitentes, entre nós, seus pequeninos, ordinários e cotidianos outros.

O sujeito político de Laclau se trataria de "sujeitos políticos [que] correspondem às vontades coletivas, resultantes de articulações políticas e ideológicas das forças históricas dispersas e fragmentadas" (ALVES, 2010, p. 86). Os próprios elementos sociais "perdem a conexão com o paradigma etapista e o seu sentido depende das articulações hegemônicas, que não estão garantidas [mais] por nenhuma lei histórica" (ALVES, 2010, p. 86).

Não há garantias. Nem para o sujeito nem mais para os fenômenos que o cercam. A única aproximação da verdade que temos são as que escoam sobre seus efeitos. Não há a possibilidade de um futuro determinado a priori. Resta-nos apostar.

Com cada vez menos sentido, então, em um líder representativo, um líder nomeador e protetor, estaríamos, também, mais submetidos ao paradigma de alguns impossíveis, dentre eles, o do impossível da representação. Com esse impossível, a queda institucional se torna inevitável e, com esta queda, a política 
não pode se dar, em mais nenhum lugar, que não, no chão. Este chão que, este sim, pode ser muito bem representado aqui como o lugar das ruas, os lugares civis - de fala, nas plataformas - do corpo, das representações - ordinárias.

As referências estão apenas como pano de fundo, feitiços abstratos e marcas do sujeito. O terreno é experimentado com uma interessante radicalidade e as práticas hegemônicas - e confluentes - se dão apenas em atos pontuais, passageiros, "pense-dance". Nada é feito para durar. Tudo funciona como "ponte" e, no momento mesmo em que se apresenta, já propõe outro lugar. 


\section{Lacan: o borrado, o incerto e o consistente}

\subsection{Cada vez mais contrato, cada vez menos instituição - "o impossível e seus poderes de subversão": nó borromeano}

É a vida que escapole a cada vez que se define uma relação, que se consolida contrato ou instituição.

Marcus André Vieira, Pequena introdução topológica à clínica do sinthoma generalizado

"A cada momento que uma "união estável" é firmada, algo fica de fora para retornar adiante" (VIEIRA, 2011, sem pág.). Mas, se estamos no impossível, então, da relação sexual, da relação total, da relação plena, harmônica e equilibrada, o que temos? O que buscar? Como compomos algum vínculo? Como... Compomos?

Uma das direções para tal dilema será a escolha que aqui fazemos, na utilização do que Jacques Lacan monta como o nó borromeano. Um espaço marcado por importante esvaziamento do sentido: "Tomar cordinhas de barbante e nós como suporte da transmissão, como faz Lacan, além de nos afastar do céu, promove, tal como em seu uso dos matemas, um radical esvaziamento do sentido" (VIEIRA, 2011, sem pág.).

A partir de tal paradigma, será por outros caminhos que passaremos a nos atar. Atarmo-nos conosco mesmos; com o que estabelecemos conexões e com o que supomos ser os registros da pólis.

O nó borromeano, conceito com o qual operaremos aqui, daria lugar a um terceiro homem para possibilitar alguma relação possivel, mas com um detalhe, com uma mudança - que move a cena em fundamental diferença e esclarece todo nosso cenário: "retira-o do céu das ideias ou do infinito da suposição. (...) traz à terra o marinheiro celeste que teria amarrado as pontas" (VIEIRA, 2011, sem pág.). Sigamos, então, para entender o ponto de vista desses autores que agregam, ainda mais, ao enriquecimento de nossa escuta sobre a passagem do mundo moderno à sua pós, como trazida por Zygmunt Bauman em nosso primeiro capítulo. 
O ser-ateu (LACAN, 2007, p. 36) se apresenta como uma das linhas de nosso nó. Vincula-se ao modo da trança, em que cada parte é independente, mas, sem uma delas, desmorona todo o jogo de cartas, toda a amarração estabelecida até então, em um triz. Na trança, não há o acasalamento entre as partes. É a sequência dos movimentos que marca seu nó. Trata-se, este, de "um arranjo, sem recurso ao marinheiro celeste" (VIEIRA, 2011, sem pág.).

Para operar com o nó borromeano, os três registros lacanianos, real, simbólico e imaginário, são convocados à cena. Melhor dizendo, articulam-se, dialeticamente, tanto na cena como para compô-la. Trata-se do nosso RSI, presente desde o início do ensino lacaniano. Mas do que tratam essas três instâncias?

Como real, buscamos entender o arcabouço da experiência, aquilo que se associa a uma imagem para se vitalizar, para ganhar vida. Como imaginário, entendemos a forma essencial de tal experiência, seu delineio, corpo e sentido. E, como simbólico, aproximamo-nos de sua localização entre oposições, nosso campo das representações. Seria este último o que "imprime no corpo imaginário representações semânticas tecidas e desatadas pelo corpo falante" (MILLER, 2016, sem pág.).

Nessa arquitetura, o simbólico teria lugar de destaque, interpondo-se às instâncias do real e do imaginário, estabelecendo o laço que dá liga e institui a vida. O simbólico apareceria, aqui, como uma instância pura na expressão de um nome próprio que, de forma significativamente fixa, marca, resume e articula o sujeito. Não é ele que possui o sentido. Este está no imaginário. Aliás, o sentido, podemos dizer, é a marca fundamental de nossa humanidade.

$\mathrm{R}$ e I se fixarem deste modo antinatural, impreciso e imprescindível do verbo, que faz junção indelével e invisível. O Simbólico é feito de nada, é um vazio de sentido entre R e I, linha de indefinível corte que faz costura. Este é o passe de mágica humano: colocar um nada, um furo, entre o real e o imaginário que faz função de cola e que exatamente por isso permite uma abertura ao imprevisível, à poesia e ao além (VIEIRA, 2011, sem pág). 
Mas Lacan não se contenta com a fórmula explicativa de que o simbólico ocupa toda a frente como elemento nodal e, mais uma vez, expande, desmonta e rearticula nossas possibilidades de percurso.

Articulado como anterior cola de toda desconjuntura, nosso terceiro homem, investido como S, passa, agora, na trança, a ser incluído de forma fugaz, como qualquer um de nossos dois outros elementos. É, então, quando nos aproximamos da perspectiva do sinthome.

Mas, antes, uma localização. A utilização das perspectivas do nó, do sinthome e do quarto elo - a que chegaremos ainda mais adiante - se dá porque aqueles três marcadores nos trazem a possibilidade de se repensar, a partir de outra e nova arquitetura, no registro dos vínculos, sejam estes mais pessoais ou coletivos, na atualidade. Ou seja, trata-se da possibilidade de pensarmos em vínculos que não se estruturam a partir de perspectivas como o vazio, o Nome-doPai e no registro do simbólico como única e fundamental composição. Mas que, ao invés disso, ajudam-nos a organizar as liquefações bauminianas, características da pós-modernidade, as dissoluções dos, até então, claros lugares de poder, e o hipotético lugar de uma liberdade que, por vezes, confunde-se com o pobre predicativo de puro caos. Acreditamos que o registro entre nó, sinthome e uma característica capacidade de (re)invenção pode nos ajudar a dar lugar a um necessário registro do possível nos dias de hoje, a partir da atualidade das construções que observamos.

Agora, sim, sigamos.

O que passamos a entender, então, é que a antiga dualidade e matemática, aparentemente mais simples, que se dão na referência a oposições, como esquerda/direita, democratas/republicanos, burgueses/proletários -, com o peso de suas respectivas referências simbólicas, muito bem costuradas, passam a se tornar menos consistentes, menos necessárias, mais abandonadas, menos, efetivamente, localizadoras de algo ou alguém.

Como diz Bauman, estamos em tempos de interregno (2016). Caminhos complexos, conflituosos e reais de uma travessia fundamental do mundo moderno à sua pós. 


\section{2 "Um Pai como um sinthoma como os outros" ou, na ordem dos "des" - sublimados, idealizados: sinthoma}

A composição do conceito de sinthoma nasce do quarto elo de nosso nó. É o giz do quadro negro ou o lápis e o papel. O imprescindível artifício que sustenta toda a amarração. É essa pura invenção que sustentará, agora, em nossa aposta, o coletivo. Ainda que uma analogia arriscada, nossa hipótese é de que há um paralelo possível entre a perspectiva do nó borromeano lacaniana e nossa atual produção de laços - de políticas encarnadas em coletivos -, alimentando, dessa forma, a produção de novas pólis. O nó borromeano une o heteróclito, une o incomum, estabelecendo, em um código inusitado, as possibilidades da coexistência do diverso e das diferenças, constituindo composição tanto estável e estabilizadora quanto dinâmica e produtiva.

O sinthoma não nomeia, como encarnava o Nome-do-Pai - o vínculo com uma identidade fixa a ser desejada, buscada, alavancada. O sinthoma forma bricolagens, amarrações e invenções que, em nossa leitura, amarram perfeitamente o sujeito contemporâneo.

Lacan localiza sua arquitetura em função do nó borromeano: "É de fato aí o que faz o que incita ao erro de pensar que esse nó seja uma norma para a relação de três funções que só existem uma para outra em seu exercido no ser que, ao fazer nó, julga ser homem" (1975-1976/2007 p. 20).

Mas o amálgama não seria tão exato, e é o sinthoma que aparece no último ensino de Lacan para estruturar tal cadeira, ainda que de modo passageiro, ainda que de forma volátil; ainda que ao seu modo. O sinthoma, como Lacan nos apresenta, perverte a tríade: "Digo que é preciso supor tetrático o que faz o laço borromeano - perversão quer dizer apenas versão em direção ao pai - em suma, o pai é um sintoma, ou um sinthoma se quiserem” (1975-76/2007 p. 21).

O sinthoma traz a importância não mais dos elementos dos nós, individualmente, mas do lugar e do como estes passam a se organizar e a se atar (SANTOS, 2002, p. 98). Serve-nos como uma nota (onde talvez possamos ler também uma rota). Uma nota de subversão para a reinvenção da própria psicanálise (LAURENT, 2018, sem pág). “Trata-se, então, [por exemplo] no nosso estudo dos novos assuntos e enredos da família, de passar de uma clínica do 
sintoma - como articulação significante do segredo familiar - à uma clínica do sinthome - como forma singular do gozo no ser falante" (BASSOLS, 2016, sem pág).

São as singularidades que se expressam, especialmente, nessa bricolagem do sinthoma e não, necessariamente, a busca pela realização de ideais constituídos em uma estrutura de massa. Segundo Santos, "Para além do nome próprio, o nome de gozo, o nome de Sinthoma, diz respeito ao que o sujeito é enquanto inabsorvível pelo nome próprio" (2002, p. 34).

É essa articulação singular, mais do que nunca, o que entra em cena, a nosso ver, constituindo tanto o corpo individual quanto o corpo social de instituições, referências, funções, encontros, políticas. É na "disseminação do sinthoma que a psicanálise localiza o mais singular e opaco do gozo do sintoma, aquilo que o torna absolutamente incomparável ao outro" (BASSOLS, 2016, sem pág).

No que cabe às nossas tentativas de localização,

Lacan já antecipara, naquele momento, a necessidade da reorganização da clínica que concluía duas décadas depois com a noção de sinthoma (...). De fato, as novas transformações familiares não se resolvem seguindo esta distinção que permitia definir seus lugares a partir do simbólico de modo mais ou menos nítido. As demandas de formar uma "família sob encomenda" e as possibilidades reais de responder a elas continua hoje inevitavelmente à deriva (...). É a estas novas derivas, e suas novas serventias, que a psicanálise de hoje (...) deverá saber responder (BASSOLS, 2016, sem pág).

É onde o sinthoma aparece, enfim, como solução. Como em um processo de análise, o sujeito entra em trabalho pelo seu sintoma e a finaliza, pelo seu sinthoma. Ambos, no entanto, ainda que de modos diferentes, expressam vias de existência, modos de se fazer presente no mundo; modos de se fazer... Este sinthoma, que se aproxima, por nomeação, do sintoma ou do transtorno (psiquiátrico), por outra via, transforma e passa a deslocar, assim, sujeito e mundo. Transtorna o mundo em uma nova direção. Esta, a foraclusão generalizada - a teoria do sintoma generalizado. Resposta a tantas e atuais mutações do mundo, exigindo, logo, também, nossa mutação teórica. Assim, aqui, situamos a entrada do vigésimo terceiro Seminário de Lacan (1975-76/2007), e a 
presença do sinthoma que apresenta o pai como um sintoma como outro qualquer, como um sintoma entre outros. Aqui, o que está em jogo não é a adequação, normalidade ou qualquer ideal a ser perseguido como uma demanda a priori, mas a tentativa de estabilização e a possibilidade de se identificar com seu próprio sintoma. A proposta, então, é do nó como modelo de amarração e, a partir disso e, tão logo, expressão e intervenção do e no real.

Bassols também localiza a espacialidade do sinthome nos tempos atuais. Fala, especialmente, da heterogeneidade do gozo como marca da atualidade, o que, segundo o autor, dificultaria o vínculo em uma política clássica (2016, sem pág.).

O sinthoma seria, então, a construção de um enlace a partir de um nó borromeano. Uma formação mista que existe como "uma escrita nova que sublinha o duplo vazio do sujeito" (SANTOS, 2006, p. 04), criação correlata ao ser falante (BASSOLS, 2016, sem pág).

Se pensamos que não há Outro do Outro, ou pelo menos que não há gozo desse Outro do Outro, precisamos de fato fazer em alguma parte a sutura entre esse simbólico que se estende ali, sozinho, e esse imaginário que está aqui. É uma emenda do imaginário e do saber inconsciente. Tudo isso para obter um sentido (LACAN, 1975-76/2007, p. 70).

Se escorregamos da aposta da boca e, mais precisamente, da palavra do Outro como entidade de localização, estabelecemos outra arquitetura para nos apoiarmos e tecermos o mundo. É isso que Lacan, então, nomeia:

Quando fazemos essa emenda, fazemos ao mesmo tempo uma outra, precisamente entre o que é simbólico e o real. Isso quer dizer que, por algum lado, ensinamos o analisante a fazer emenda, a fazer emenda entre seu sinthoma e o real parasita do gozo. O que é característico de nossa operação, tomar esse gozo possível, é a mesma coisa que o escreverei como gozo-sentido [j'ouis-sens]. É a mesma coisa que ouvir um sentido (LACAN, 1975-76/2007, p. 70-71).

Como diz Lacan "é de suturas e emendas que se trata" (1975-76/2007 p. 71), e não de revoluções totais, de sujeitos totais, perfeitos, acabados, completos, harmônicos. Crenças que, a não ser por propostas de violência significativamente 
presentes ainda nos dias de hoje, parecem não se estruturar mais como narrativa e proposta básica.

Como obra inacabada de Lacan, é claro que aproximamos o paradigma do sinthome de uma leitura possível, parecendo-nos dialogar, significativamente, com as mudanças e deslocamentos do sujeito com ele mesmo, do sujeito com o outro e do sujeito com sua produção com e da pólis (talvez tendo, esta sim, como analogia, a política como seu $4^{o}$ elo, algo a se pesquisar em outro momento) nos dias de hoje. O sinthome parece se tratar, então, de um véu que dá liga e produz. Algo que dá liga para essa outra coisa quando a função paterna aparece de modo mais desligado, mais descatexizado, mais deslocado. Ele - o sinthome - aparece, então, nesse outro lugar onde as grandes referências já não parecem mesmo significar tanto e não há mais o grande enlevo do lugar de exceção - este lugar que parecem todos hoje poderem ocupar porque, a bem da verdade, todos o sabem ninguém mais poder fazê-lo.

O conceito de sinthoma se aproxima do significante mestre, apresentando, de forma bem contemporânea, seu rearranjo na estrutura. A partir dele, laços e política continuam a se dar, mas, a partir dessa direção, não sem a relação com um outro - outro-horizontal, outro-linha-de-trança, outro-parceiro -; com o outro que, ainda que imprescindível para se tecer a trama, é um outro qualquer. Não é uma referência central, nem referência dominante, nem a sua imagem e semelhança. Criaríamos e nos localizaríamos na teia pós-moderna, então, dessa maneira. A partir de outras conexões. "Pois se não há relação sexual, então, há sintomas. Ele conecta o desconexo e essa é a única conexão possível” (SANTOS, 2006, p. 96).

Talvez, por aqui, possamos nos aproximar, então, da perspectiva do encontro das singularidades de Alemán e Laclau, na espacialidade mais real dos seus diferentes interlocutores por proximidade do real, e não de uma distância imaginária e, especialmente, simbólica, de seus pontos extremos, de seus pontos externos, de seus pontos gerais. Ainda que, também, de seus espaços comuns, o espaço que conceitua suas solidões comuns como encontro pelas diferenças.

O território polêmico, mas também desejado é, enfim, o de aposta no sujeito. Mais especificamente, o de aposta nos mercadores de uma leitura da psicanálise lacaniana como ângulo que delineia o sujeito. Essa é nossa aposta ao 
nos aproximarmos dessa leitura da psicanálise sobre o sujeito atual - suas disrupções, seus deslocamentos quanto às referências mais globais e fixas. Pensar em uma política que, ela também, por sua vez, pense o sujeito como real é necessária matéria-prima e conjunto de ferramentas para se arquitetar.

As conexões extrapolam as instituições e isso, como prática, não é, necessariamente, algo novo. Isso é novo como afirmação. Como um lugar de fala, como lugar legítimo. Isso é novo como recorte ético. Como, enfim, defesa de que há outras possibilidades para se ler o sujeito e que isso, em absolutamente nada, tem, em si, a ver com se aproximar do caos, do descaso, da indiferença, do niilismo e da destruição do próprio sujeito, de seus marcadores relacionais e da própria arquitetura possível de uma política que dê pauta a uma estruturação coletiva. Mais que isso, essa perspectiva tem a ver com se aproximar dos homens. Homens não simplesmente como indivíduos de consumo, mas como sujeitos de desejo. Homens que se aproximam de si mesmos, enquanto estruturas; que se aproximam dos outros, enquanto relação; e que estabelecem códigos sociais que se conectam, finalmente, às suas marcas mais íntimas; e, logo, como ser fruto da relação (possível e impossível) coletiva. Esse também é o nosso ato instituinte, sem a materialidade de uma instituição que, em estrutura de massa, funcione à base apenas da repetição e que, ainda assim, amarra toda a cena. Trata-se, portanto, do momento em que o homem se aproxima do próprio homem e a civilização pode ser instituída por esses e não por Outros.

\section{3 "Quanto ao uso besta dos nós", quanto ao uso besta de nós: marcas e invenções}

Chegamos ao fim, então, aproximando-nos deste lugar tão fresco, surpreendente e curioso, que habitamos, por fim, querendo ou não, todos nós. Com as grandes referências de identificação meio débeis nos tempos atuais, localizamo-nos no território do ineficaz, do improdutivo, do duvidoso, do que rateia, do que é incerto, do que é furo.

Como já assinalado antes, Lacan já nos dissera sobre o impossível da relação sexual. Ou seja, que não há relação de completude, de chegada, relação final, tão vendida, tão comum, tão internalizada, por tantos anos a fio, como na 
nossa aposta civilizada. Da crença nas instituições, chegamos aos voláteis, passageiros coletivos. Nada é feito para durar. Questiona-se se isso é necessariamente algo ruim e se aposta que não.

E mais: entendemos, aqui, que lidar com o fracasso - ou com o que consideramos assim até hoje (nossos hiatos, furos, falhas, vergonhas, verrugas) é também, de certo modo, não adormecer no sono profundo da espera. A espera de um outro que nos nomeie e nos apresente, por este meio, à nossa própria localização.

Com a cadeia interpretativa do nó e do sinthoma, temos a possibilidade de nos sensibilizarmos por outra localização. Trata-se, talvez, do Um sem par (MONTEIRO, 2013, sem pág). De qualquer modo, podemos nos distanciar daquela que parecia a única possibilidade, a do caos que se esperava com a queda das grandes referências, com a humanização de Deus, com um pai parceiro.

As marcas do sujeito e seu eterno companheiro - a instância do inconsciente - parecem ser guias satisfatórios, possíveis, interessantes e ricos de possibilidades. Assim, desdobrando o impossível da relação sexual, chegamos à seguinte colocação: chegamos a uma espécie de aforisma do impossível, no Seminário, livro 20 (1972-1973/2008), com a justaposição entre o “não acontecer" e “o que não cessa de se escrever” (LACAN, 1972-1973/2008, p. 92). Deslocado o eterno, tudo se faz - quase - a cada vez. Referimo-nos, aqui, a um quase, porque marcas do sujeito são pontos de ancoragem, pontos descobertos de ancoragem disso se trata o sinthoma.

Com isso, vemos que o impossível da relação sexual não paralisaria a possibilidade das relações, mas que, ao contrário, faria com que esta insistisse em se inscrever. Assim, a falta de uma relação original, natural, não impediria o estabelecimento de outras relações. Tal falta instigaria sua busca e, justamente, por ela, de certa forma, possibilitaria que as relações pudessem se proliferar. É essa a cadeia que marca o sujeito e seu deslizamento, inclusive, na própria história. Esses são nossos poderes de subversão. Dos fracassos, a insistência. Dos fracassos, o inventivo.

Os artifícios dessa estrutura - e, no que supomos, os artifícios do agora estariam muito distantes dos nossos delineados anteriores: obras, ideais, grandes 
estruturas, "são bem mais o que J.-A. Miller situa como invenção, montagem a partir de "materiais preexistentes", restos, pedaços, fragmentos de discurso (VIEIRA, 2011, sem pág.).

Ou seja, na queda das grandes - e massificadas - referências, continua-se a tecer o sujeito, continua-se a tecer a relação entre sujeitos; continua-se a tecer o mundo.

Não se trata de caos ou o fim, mas de um deslocamento importante de um modo específico de fazê-lo. Outros materiais e outras tessituras passam a ser matéria prima para a existência. E “a revolução não é menor por se referir apenas às revoluções celestes" (LACAN, 1960/1998, p. 811).

Em todas essas quedas, o Nome-do-Pai não norteia mais o nome-do-filho e o mundo dos significados desliza, sistemática e constantemente para o mundo dos significantes. O neurótico moderno optaria pela falta da marca, mas, na estrutura moderna, parece que tal operação começa a deslizar.

De fato, o significante é o rastro deixado pelos encontros com o Outro, signo com que o ferro da linguagem, em uma metáfora célebre de Lacan, marca seu gado, mas é ao mesmo tempo furo na significação, pois essa marca não tem sentido, é pura contingência - tal como uma cicatriz, que pode ser lida e contar uma história ou pode ser vazia de significado, apenas traço que distingue. Essa ambiguidade fundamental do significante é metaforizada pelo quarto elo (VIEIRA, 2011, sem pág).

Santos agrega e radicaliza: "Se caminharmos na direção do real, no limite, dissolvemos todas as identificações" (SANTOS, 2002, p. 55). Nesta fase do ensino de Lacan, o sujeito é, como nunca, apreendido por sua atmosfera singular, que o institui como Um. Logo, o que o nomeia também não vem mais do Outro, e é aqui que se encontra a marcação nodal de sua singularidade e sua afinidade com o sintoma no registro que aqui desenvolvemos, o do sinthoma (SANTOS, 2002, p. 28).

Obviamente, neste cenário, o outro continua existindo, mas, na sua precariedade, localiza-se enquanto parceiro e não enquanto Outro dominante. Mudança de referencial que parece retirar o sujeito de sua categoria de espera, 
sono, expectativa e ansiedade por nomeação, para o lugar de um saber-fazer possível. "Trata-se do eu sou o meu sinthoma" (SANTOS, 2002, p. 29).

E esse sujeito identificado ao seu sinthoma já não é outro total, já é outro que se dimensiona no inacabado, no fictício, na contingência. Diante da exaustão da expectativa da espera, já é sujeito furado, sujeito que bricola a própria existência - sua solução possível.

\begin{abstract}
Eu posso retomar mais cuidadosamente essa questão em uma outra ocasião, mas, só para concluir, Miller termina propondo que, com respeito a Lacan, nós temos que fazer uma diferença entre o Lacan que trabalha com a falta - que é um conceito eminentemente do campo simbólico -, e o Lacan que trabalha com o furo - que é um conceito que faz sentido no campo da topologia dos nós. Enquanto no caso da falta se trata de substituição, no que se refere ao furo, o acréscimo só pode se dar por suplência (SANTOS, 2002, p. 33).
\end{abstract}

E, na suplência, bricola-se a existência. Inscreve-se com língua nunca antes tão própria, nunca tão sabidamente própria. Encontra-se uma língua, uma língua diversa que faz lei de alteridade coletiva, que não viola o real para encaixálo, para moldá-lo; que vive em sua companhia.

Seríamos todos, então, a partir desse último ensino de Lacan, articulados por nova configuração. É aqui mesmo que "os conceitos e as noções fundamentais da psicanálise são retomados por Lacan a partir de novos ângulos" (MANDIL, 2018, sem pág). Há a invenção de uma outra maneira de gozar, em que seus parceiros (con)vivem mais em trocas do que em normas que se fundamentam na repetição. Essa seria a solução que nos ajudaria a entrar neste mundo a partir dos deslocamentos que nos descrevem. Assim, o sintoma não apareceria mais como um problema, interpretação que embasa muitos entes da cultura e, inclusive, de boa parte da psicanálise até aqui, mas passa a aparecer como solução, sinthoma.

Tal mudança se trata não apenas de depósito conceitual; "Lacan introduz esta articulação ortográfica, escrevendo sinthoma para indicar que o que era um problema sobre a ótica do inconsciente é uma solução do ponto de vista do real" (SANTOS, 2006, p. 106). Que esteja(mos), então, aptos às suas leituras, intenções e experiências. Que consigamos não apenas malograr o presente, mas o apresentar como possibilidade, como caminho, como furo de bricolagem. "Que o inesperado 
nos faça [então] uma surpresa" ${ }^{\prime 10}$, e que essas surpresas possam se estender em nossa inscrição de mundo.

Que seja mais a respeito das singularidades que se trate do que de nosso respaldo em nossos cabisbaixos eternos. Assim, pontuam-se nossos atos instituintes que pouco se marcam, em compromissos, a priori, com o tempo, sua durabilidade, mas se esculpem em funções pontuais que podem ou não marcar o sujeito e seu espaço. Quando um pouco mais duradouros, sustentam-se do laço, da multiplicação de seus nomes em uma multidão interessada, não por organizações pré-fixadas que magistralmente sustentam a manada, mas que, por expressão desse encontro, define, em parceria, a montagem - e desmontagem - do real, insistente e constante, fazendo do impossível "o que não cessa de se escrever" (LACAN, 1972-1973/2008, p. 92) - nosso eterno.

\footnotetext{
${ }^{10}$ Trecho da música Eu e a brisa, de Johnny Alf, 1997.
} 


\section{Conclusão}

Segundo Jacques-Alain Miller, estamos em fase de saída da era do Pai. Com outro discurso a emergir, desbanca-se o lugar da tradição e almeja-se a inovação. Na queda da hierarquia, entram os processos de rede, (re)agrupamentos, coletivos. Mudando os lugares, também se movem as representações. A expectativa é com o futuro e há certa fragilidade quanto ao passado. E o feminino, este sim, se funda no lugar do viril. O Édipo não é mais a única resposta, nem para a organização, nem para a localização do sujeito e seu desejo. É apenas sua forma normalizada.

É o que Zygmunt Bauman chama de momento de interregno. Estamos em passagem. Em deslocamentos internos e, logo, externos. Neste percurso, dentre outros, o psicanalista Jorge Alemán e o cientista político Ernesto Laclau foram, em nossa dissertação, extremamente gregários com suas articulações entre psicanálise e política. Ao se debruçarem sobre tal tarefa, no entanto, acabaram por não deixar inócuas nem a psicanálise, nem a política. Ambos parecem ver na possibilidade de produção de um espaço comum, também, entre estes saberes, um encontro - um encontro entre diferenças, que podem vir a produzir novos atos. Chamamo-los, com Alemán, de "atos instituintes" (2010, p. 27). São autores que se debruçam sobre as possibilidades de potências desses dois campos, na intenção de trazer reflexões e respostas em possíveis produções para os impasses da atualidade. Bauman, aliás, nos descreve bem estes últimos.

Alemán e Laclau buscam criar novos pontos de encontro, pontos de partida, de chegada e de passagem, intentando não apenas compreender, mas atuar, tecer possibilidades e colaborar com o delineamento de caminhos diante dos efervescentes - e polêmicos - movimentos políticos na atualidade. Para tanto, voltam ao mais básico: voltam ao sujeito. Propõem uma leitura a partir da psicanálise lacaniana, para a compreensão desses movimentos e para, assim, atar o mundo desconjuntado da pós-modernidade à imagem e semelhança deste sujeito, suas possibilidades, desajustes e invenções. Traçam rotas de fuga que se dirigem ao lado oposto do caos, do niilismo ou da simples volta da barbárie, em suas, desde há tempos, vestes de segurança. 
Esses autores, assim como outros, parecem buscar, hoje, uma espécie de sanidade inventiva, ou loucura aterrada. Buscam um singular que faça laço e coletivos, não massa. Busca-se e se supõe a possibilidade de um singular que, inerente ao desamparo e à espacialidade humana, como um todo, necessita, busca e deseja liga, não amálgama. A primeira, esta sim, eternizada.

Esse projeto encontra aqui, então, o seu suporte na possibilidade de um outro-parceiro, ativista às respostas que apenas visam a consumir o indivíduo (quem dirá o sujeito). Processo atual em que a democracia se torna, facilmente, apenas simulacro. Como resposta a isso, aparecem as necessárias coletividades e a valorização do volátil, não apenas como perda, vazio, mas como furo necessário para a produção, para o movimento e para a insistência; para o que "não cessa de se escrever" (LACAN, 1972-1973/2008, p. 92).

Todos os autores aqui apresentados buscam, cada um à sua maneira, traduzir seu tempo. Encontro pelas diferenças. Encontro empírico de proposta a ser alcançada. Afinal de contas, o que não se deseja mais "é a visão do político como espaço fechado e homogêneo" (LACLAU, 1983, sem pág). Deseja-se e se necessita de interlocuções. E como proposta que subverte, oferecemos o nosso "sem sentido".

O contato é, enfim, o dado humano que possibilita outros e novos caminhos. A conexão, por mais simples que possa parecer - e talvez por isso mesmo -, é nosso carro chefe. As fragilidades, mesmo parecendo nunca ter estado tão expostas, por outro lado, talvez, inclusive, porque assim: explícitas, verbalizadas, ultrapassando a melancolia, articulam-se no incômodo, visando à (r)existência. Uma existência que também, como nunca, produz novos e frescos atos. Atos lógicos, atos de tempos lógicos - nossa marca de tempo, nossa única resposta de eternidade.

$\mathrm{Na}$ rotina de efervescentes mudanças, subvertem-se os paradigmas, entendendo os conflitos como inerentes e não mais como elimináveis. Transborda-se, assim, o mundo, dada a possibilidade da entrada de todos os elementos em cena. Mesmo aqueles que, antes, tão escondidos, tão recalcados, tão proibidos. Para este mundo, ainda não temos muitas explicações. Trata-se de um mundo do qual nos aproximamos de dentro mesmo do cenário - configuração, se 
não ideal, real, a possível. Fato, aliás, que cabe bem nas nossas discussões com este burlesco ideal.

Desconstrói-se, assim, hoje, gradativamente, tudo o que foi construído até então. Realiza-se reconstruções. E ao sintagma do nó líquido, oferecemos a trança e nossas novas marcações.

A temática atual é a do empoderamento do que há de resto em todos nós. Nossos hiatos, nossos desenquadres, nossos fora do eixo. É do real de se ver pueril, de se ver falível, de se ver mortal. Assim, não há mais a aposta no futuro distante ou em um céu a se esperar. Há só o ordinário, agora. O tempo finito. Nosso tempo fatal.

Fica aqui, então, nossa aposta. Nossa subversão. Viver o dia-a-dia, criar na semana, amar no mês. Lutar como quem faz o almoço, resistir como quem ceia o jantar. Revolucionar o cenário todas as segundas, terças e quartas. Subverter o sistema das narrativas ideais, dos sonhos-margarinas, dos exaustivos - e obrigatórios - nomes de demandas de amor. Saber-se só; saber-se. Saber-se incompleto, estruturalmente e, a partir disto, estabelecer $U m$; estabelecer laço, estabelecer coletivo e estender-se às políticas rotineiras: lugares, ordinários, de fala, corpos-plataforma, representantes civis. Viver uma vida café com leite. Sem demora.

Pela estrutura do sinthoma, temos o invólucro que amarra e suporta o sujeito. Invólucro que reúne suas diferenças, a diversidade de suas marcações, elementos que jurávamos, até então, impossíveis de conviver. E a partir deste invólucro, outro buscado: o invólucro do encontro entre os corpos. A reunião das diferenças pelo encontro das solidões, amarrando e suportando o ato instituinte, nosso possível da política hoje. Nosso desejo, com esta dissertação, é de que tais formas possam se espalhar, agregadas às narrativas de valor. Operação fundamental para se fugir da barbárie, há tempos não tão próxima. Há tempos não tão ruidosa.

Dúvidas, contradições, mudanças de ideia e de opiniões, que todas essas questões se aproximem cada vez mais da construção do humano. É isso com que parece nos apelar Alemán e Laclau. Convite aceito. 
Sujeitos descentrados, respondendo aos impasses de seu tempo. Esse também é o campo, atualmente, da psicanálise.

\begin{abstract}
Lacan aborda o que, em uma análise, funciona como escrita. Não seus aspectos formais, burocráticos, mas suas propriedades de enlace, de manter unidos elementos heterogêneos que, a princípio, nada teriam a ver entre si, a não ser seus traços de contingência. (VIEIRA, 2018a, p. 96).
\end{abstract}

É nessa direção que a escrita do sujeito hoje nos parece ser seu sinthoma. Este, seu texto contingencial que lhe dá invólucro, que lhe faz existir, que lhe faz coexistir, que lhe faz produzir. Por sua vez, a escrita do coletivo, hoje e, se nos permitirmos dizer, da política, seria, a nosso ver, nosso ato instituinte: amarração da existência de vários e execução das transformações em cena. Essa é nossa revolução ordinária e talvez, também, por isso mesmo, efetiva, já que, após cada ato, há apenas a contingência do funciona/não funciona, e não um relatório a ser entregue ao pai, ao chefe, a Deus ou ao exército, e suas infinitas expectativas de aprovação.

Por mais contraditória que possa parecer a ideia de contingência, então, um importante ponto para nossa ancoragem. Pós sabida, parte do cenário. A cada novo ato, configuração da história. Marcando sujeito, coletivos e os trajetos da pólis. Uma maneira de se colocar, de se localizar e de se deslizar no curso do mundo-discurso (MILLER, 2011, sem pág).

Afinal de contas, a descoberta freudiana diz respeito mesmo aos dejetos. O sonho, o lapso, o ato-falho... O sintoma. Descoberta que, se levada a sério, ofertanos oferta alguma chance. Esta descoberta diz respeito ao que é mais parcial, mais pontual, mais marcante do sujeito. Ao que não é falta - para ser encontrado -, mas furo e marca.

Que nos aproximemos, então, do homem e, a partir dele, aí sim, possamos desdobrar nossas ações no mundo que leva seu nome, e, quem sabe, talvez, desdobrar nossas ações em um mundo sinthome. 


\section{Referências bibliográficas}

ALEMÁN, J. Para una izquierda lacaniana. Grama, Buenos Aires: 2010.

ALEMÁN, J. Soledad: Común: Política y psicoanálisis. ICF Granada: 2013. Disponível em: < https://www.youtube.com/watch?v=PaeuK IISVw>. Acesso em: 14.06.2018.

ALEMÁN, J; PUJÓ, M. Jorge Alemán y el debate contemporâneo. Antifilosofía e izquierda lacaniana. In: Revista do centro de Estudos em Semiótica e Psicanálise. PUC-SP. São Paulo, 2013. Disponível em: $<$ https://revistas.pucsp.br/index.php/leituraflutuante/article/view/16109/121 60>. Acesso em: 15.06.2018.

ALVES, A. R. C. O conceito de hegemonia de Gramsci a Laclau e Mouffe. 2010. Disponível em: <http://www.scielo.br/pdf/ln/n80/04.pdf>. Acesso em: 20.11.2018.

BAUMAN, Z. O Mal estar na pós-modernidade. Rio de Janeiro: Zahar, 1998.

Globalização, as consequências humanas. Rio de Janeiro: Jorge Zahar Ed., 1999a. $1999 b$.

Modernidade e ambivalência. Rio de Janeiro: Jorge Zahar Ed.,

. Modernidade Líquida. Rio de Janeiro: Jorge Zahar Ed., 2001.

Comunidade: a busca por segurança no mundo atual. Rio de Janeiro: Jorge Zahar Ed., 2003a.

. Ética pós-moderna. São Paulo: Paulus, 2003b.

A vida fragmentada. Lisboa: Relógio D’água Editores, 2007a.

. Tempos Líquidos. Rio de Janeiro: Jorge Zahar Ed., $2007 \mathrm{~b}$.

. Entrevista exclusiva Zygmunt Bauman. Núcleo de Pesquisas em Estudos Culturais Npec: 2011. Disponível em: $<$ https://www.youtube.com/watch?v=1miAVUQhdwM\&t=3s >. Acesso em: 19. 07.2018.

A fluidez do 'mundo líquido' do Zygmunt Bauman. 2016. Disponível em: $<$ https://www.youtube.com/watch?v=7P1MAZXFVG0\&t=629s $>$. Acesso em: 16.10.2018.

BAUMAN, Z; DESSAL, G. O retorno do pêndulo. Rio de Janeiro: Jorge Zahar Ed., 2017. 
BASSOLS, M. Famulus. In: Lacan XXI, Rev. FAPOL Online. 2016. Disponível em: <http://www.lacan21.com/sitio/wpcontent/uploads/2016/10/lacan21 2016 volume2 PT-1.pdf>. Acesso em: 10.01.2019.

BERNARDES, A. C. Aí estamos. In: Rio de Janeiro, Encontro brasileiro do Campo Freudiano. 2018. Disponível em: < http://encontrobrasileiro2018.com.br/ai-estamos/>. Acesso em: 04.02.2019.

BROUSSE, Marie-Hélène. A queda do falocentrismo. In: Produção da Escola Brasileira de Psicanálise - XXII Encontro Brasileiro [EBCF]. 2018, 9:17 min, son., color. Disponível em: $<$ https://www.youtube.com/watch?v=HvMzXczePiU >. Acesso em: 14.11.2018.

DUFOUR, R. A arte de reduzir as cabeças. Rio de Janeiro: Companhia de Freud, 2005.

A política da cidade. In: Página Dany-Robert Dufour,

2016. Disponível em: <http://www.dany-robert-dufour.fr/?p=1724>. Acesso em: 04.11.2018.

ESTRELLA, R. Uma esquerda lacaniana? Entrevista com Jorge Alemán. In: Blog da livraria e editora Subversos. Rio de Janeiro, 2017. Disponível em: <http://subversos.com.br/uma-esquerda-lacanianaentrevista-com-jorge-aleman>. Acesso em: 14.06.2018.

FIGUEIROA, J. C. L. Escola, Psicanálise e Democracia. In: Boletim Eletrônico Conselho Deliberativo da EBP. 2018. Disponível em: $<$ http://www.ebp.org.br/1por1/2018/03/02/escola-psicanalise-edemocracia-jose-carlos-lapenda-figueiroa>. Acesso em: 09.01.2019.

FREUD, S. (1913-1914) Totem e tabu. In: Edição Standard Brasileira das Obras Psicológicas Completas de Sigmund Freud. Volume XIII. Rio de Janeiro: Imago, 1969.

. (1921) Psicologia das massas e análise do eu e outros trabalhos. Rio de Janeiro: Companhia das letras, 2011.

. (1927) O futuro de uma ilusão. In: Edição Standard Brasileira das Obras Psicológicas Completas de Sigmund Freud. Volume XXI. Rio de Janeiro: Imago, 1969.

(1930 [1929]) O mal-estar na civilização. In: Edição Standard Brasileira das Obras Psicológicas Completas de Sigmund Freud. Volume XXI. Rio de Janeiro: Imago, 1969.

HERZOG, R. O laço social na contemporaneidade. In: Revista Latinoamericana de psicopatologia fundamental. 2004. Disponível em: 
<http://www.scielo.br/scielo.php?script=sci arttext\&pid=S1415-

47142004000300040>. Acesso em: 11.01.2019.

LACAN, J. (1953) O simbólico, o imaginário e o real. In: Nomes-do-Pai. Rio de Janeiro: Jorge Zahar Ed., 2005b.

. (1958-59). O Seminário, Livro 6: o desejo e sua interpretação. Rio de Janeiro: Jorge Zahar Ed., 2008.

. (1960). Subversão do sujeito e dialética do desejo no inconsciente freudiano. In: Escritos. Rio de Janeiro: Jorge Zahar Ed., 1998.

. (1962-63). O Seminário, Livro 10: a angústia. Rio de Janeiro: Jorge Zahar Ed., 2005.

. (1966-67) A lógica do fantasma. Versão do Centro de estudos freudianos do Recife, ano 2008.

. (1967-68) Meu ensino. Rio de Janeiro: Jorge Zahar Ed., 2006.

. (1968-69) O Seminário, Livro 16: de um Outro ao outro. Rio de Janeiro: Jorge Zahar Ed., 2008.

. (1972-73). O Seminário, Livro 20: mais, ainda. Rio de Janeiro: Jorge Zahar Ed., 2008.

2018.

. (1973-1974). Os não-tolos erram/Os Nomes do Pai. Editora Fi:

. (1975-76). O Seminário, Livro 23: o sinthoma. Rio de Janeiro: Jorge Zahar Ed., 2007.

LACLAU, E. Os novos movimentos sociais e a pluralidade do social. In: Revista Brasileira de Ciências Sociais. 1983. Disponível em: $<$ https://scholar.google.com/scholar lookup?title=Os+novos+movimentos+ sociais+e+a+pluralidade+do+social\&author=LACLAU+Ernesto\&publicatio n year=1986\&journal=Revista+Brasileira+de+Ci\%C3\%AAncias+Sociais\& volume=2\&pages=41-7>. Acesso em: 06.02.2018.

. La razón populista. México: Fondo de Cultura Económica, 2005.

LACLAU, E. MOUFFE, C. Hegemomía y estratégia socialista: Hacia una radicalización de la democracia. Madrid: Letra e, 1987. Disponível em: <https://www.perio.unlp.edu.ar/catedras/system/files/laclau ernesto hegemonia y estrategia socialista pdf.pdf>. Acesso em: 16.07.2018.

LAURENT, E. Disrupção do gozo nas loucuras sob transferência. In: Lacan em $2018 . \quad$ Disponível em: $<$ http://lacanempdf.blogspot.com/2018/04/disrupcao-do-gozo-nasloucuras-sob.html>. Acesso em: 04.01.2019. 
LINDENMEYER, C. A Antropologia Psicanalítica: uma chave para pensar o contemporâneo: entrevista com Paul-Laurent Assoun. In: Rev. Latinoam. Psicopat. Fund. São Paulo: 2018. Disponível em: <http://www.scielo.br/pdf/rlpf/v21n3/1415-4714-rlpf-21-3-0431.pdf. >. Acesso em: 13.02.2019.

MACÊDO, L. F. Notas sobre biopolítica e política da psicanálise. In: Blog da Editora e Livraria Subversos. 2014. Disponível em: https://subversos.com.br/notas-sobre-biopolitica-e-politica-da-psicanalise1/. Acesso em: 21/02/2019.

MANDIL, R. Disciplina do comentário. In: Encontro Brasileiro do Campo Freudiano: 2018.2 Disponível em: $<$ http://encontrobrasileiro2018.com.br/disciplina-do-comentario-rammandil>. Acesso em: 04.01.2019.

MENDONÇA, D. Emancipação e Diferença, de Ernesto Laclau. In: Revista Estudos Políticos. 2012. Disponível em: <http://revistaestudospoliticos.com/wp-content/uploads/2012/04/4p130135.pdf >. Acesso em: 16.12.2018.

MENDONÇA, D e VIEIRA JUNIOR, R. Rancière e Laclau: democracia além do consenso e da ordem. In: Revista Brasileira de Ciência Política. 2014. Disponível em: $<$ http://www.scielo.br/scielo.php?pid=S0103$33522014000100005 \&$ script $=$ sci abstract\&tlng=pt>. Acesso em: 20.12.2018.

MEZAN, R. Tempo de muda, ensaios de psicanálise. Rio de Janeiro Companhia das Letras, 1998.

MILLER, J.-A. Uma fantasia. In: Página do VIII Congresso da Associação Mundial de Psicanálise AMP. Buenos Aires, 2004. Disponível em: $<$ http://2012.congresoamp.com/pt/template.php?file=Textos/Conferenciade-Jacques-Alain-Miller-en-Comandatuba.html>. Acesso em: 12.11.2018.

A Salvação pelos dejetos. In: Perspectivas dos escritos e outros escritos de Lacan - entre desejo e gozo. Rio de Janeiro, Jorge Zahar Ed.: 2011.

. O inconsciente e o corpo falante. In: Associação mundial de psicanálise. 2016. Disponível em: $<$ https://www.wapol.org/pt/articulos/Template.asp?intTipoPagina=4\&intPu blicacion=13\&intEdicion=9\&intldiomaPublicacion=9\&intArticulo=2742\&intl diomaArticulo=9 > . Acesso em: 09.02.2019.

MONTEIRO, C. P. Editorial. In: Boletim Haum \#008. Haun, Sem. Internacional ad escola Brasileira de Psicanálise, Leituras do Seminário 19:... ou pior. 2013. Disponível em: <https://www.ebp.org.br/haun/boletins/008.asp.>. Acesso em: 10.01.2018 
OLIVEIRA, G. F. T. Novos rumos da psicanálise como a clínica do malestar. In: Estudos e pesquisa em psicologia - UERJ. 2008. Disponível em: <http://pepsic.bvsalud.org/pdf/epp/v8n1/v8n1a12.pdf>. Acesso em: 11.01.2019.

PALLARES-BURKE, M.L.G. Entrevista com Zygmunt Bauman. In: Tempo Social (Rev. Sociologia USP). 2004. Disponível em: $<$ http://www.scielo.br/scielo.php?script=sci_arttext\&pid=S0103$20702004000100015 \&$ Ing=pt\&nrm=iso\&tlng=pt>. Acesso em: 10.01.2018.

RODRIGUES, G.V. O triunfo da religião e a incerta presença da psicanálise. Belo Horizonte, 2015. Disponível em: $<$ http://pepsic.bvsalud.org/scielo.php?script=sci arttext\&pid=S010273952015000200007>. Acesso em: 23.11.2018.

SANTIAGO, J, Efeito-Charlie e a política do não-todo. In: Minas com Lacan. 2015. Disponível em: http://minascomlacan.com.br/efeito-charliee-a-politica-do-nao-todo/. Acesso em: 21/02/2019.

SANTOS, T. C. Paradigmas do último ensino de Lacan. In: Sephora, Programa de pós-graduação em Teoria psicanalítica (UFRJ). 2002. Disponível em: $<$ http://www.isepol.com/down_pos/livro_paradigmas lacan.pdf $>$. Acesso em: 17.01.2019.

Sinthoma: corpo e laço social. In: Sephora, Núcleo de pesquisa sobre o moderno e o contemporâneo (UFRJ). 2006. Disponível em: $<$ http://isepol.com/down pos/sinthomacorpoelacosocial.pdf $>$. Acesso em: 16.01.2019.

SALLENAVE, D. "L'alibi de la compassion". In: Le Monde Diplomatique. 1995. Disponível em <https://www/mondediplomatique.fr/1995/07/SALLENAVE/6490>. Acesso em: 16/02/2019.

TIZIO, H. Novas modalidades do laço social. In: Isepol. 2006. Disponível em: $\quad<$ http://www.isepol.com/asephallus/numero 04/artigo 03.htm>. Acesso em: 14 nov. 2018.

VIEIRA, M. A. A política do sintoma II - Sobredeterminações. In: Litura. 2008a. Disponível em: $<$ http://www.litura.com.br/curso repositorio/a politica do sintoma ii pdf 1.pdf>. Acesso em: 16.01.2019.

2008b. A política do sintoma III - Freud e as comunidades. In: Litura.
Disponível em: <http://www.litura.com.br/curso repositorio/a_politica_do sintoma_iii_pdf 1.pdf>. Acesso em: 19.01.2019.

Pequena introdução topológica à clínica do sinthoma generalizado. In: Litura. 2011. Disponível em: http://www.litura.com.br/artigo repositorio/introducao a clinica do sintom a generali 1.pdf. Acesso em: 21/02/2019 
A escrita do silêncio (voz e letra me uma análise). Rio de Janeiro: Subversos Livraria e Editora, 2018a.

A psicanálise do fim do mundo. Por uma aposta no sujeito dividido. In: Blog da Subversos Livraria e Editora. 2018b. Disponível em: <https://subversos.com.br/tag/marcus-andre-vieira/>. Acesso em: 04.01.2019.

Falocentrismo. In: Produção da Escola Brasileira de Psicanálise - XXII Encontro Brasileiro [EBCF]. 2018c, 11:43 min, son., color. Disponível em: <https://www.youtube.com/watch?v=8fiYHQJZ5O0>. Acesso em: 14 nov. 2018c. 